Article

\title{
Insights for Landfill Site Selection Using GIS: A Case Study in the Tanjero River Basin, Kurdistan Region, Iraq
}

\author{
Arsalan Ahmed Othman ${ }^{1,2, *}$, Ahmed K. Obaid ${ }^{3,4}{ }^{(0}$, Diary Ali Mohammed Al-Manmi ${ }^{5}$, Mohammad Pirouei ${ }^{6}$, \\ Sarkawt Ghazi Salar ${ }^{7}$, Veraldo Liesenberg ${ }^{8}{ }^{(D}$, Ahmed F. Al-Maamar ${ }^{1}$, Ahmed T. Shihab ${ }^{1}$, Younus I. Al-Saady ${ }^{1}$ \\ and Zaid T. Al-Attar ${ }^{3}$
}

check for

updates

Citation: Othman, A.A.; Obaid, A.K. Al-Manmi, D.A.M.; Pirouei, M.; Salar, S.G.; Liesenberg, V.; Al-Maamar, A.F.; Shihab, A.T.; Al-Saady, Y.I.; Al-Attar, Z.T. Insights for Landfill Site Selection Using GIS: A Case Study in the Tanjero River Basin, Kurdistan Region, Iraq. Sustainability 2021, 13, 12602. https://doi.org/10.3390/ su132212602

Academic Editor: Luca Salvati

Received: 20 October 2021

Accepted: 12 November 2021

Published: 15 November 2021

Publisher's Note: MDPI stays neutral with regard to jurisdictional claims in published maps and institutional affiliations.

Copyright: (c) 2021 by the authors. Licensee MDPI, Basel, Switzerland. This article is an open access article distributed under the terms and conditions of the Creative Commons Attribution (CC BY) license (https:/ / creativecommons.org/licenses/by/ $4.0 /)$.
1 Iraq Geological Survey, Al-Andalus Square, Baghdad 10068, Iraq; ahmed.f@geosurviraq.iq (A.F.A.-M.); ahmedshihab@geosurviraq.iq (A.T.S.); younusalsaady@geosurviraq.iq (Y.I.A.-S.)

2 College of Engineering, Department of Petroleum, Komar University of Science and Technology, Sulaimaniyah 460013, Iraq

3 Department of Geology, University of Baghdad, Baghdad 10068, Iraq; ahmedobaid@uobaghdad.edu.iq (A.K.O.); bce.19.62@grad.uotechnology.edu.iq (Z.T.A.-A.)

4 Department of Earth Sciences, University of Durham, Durham DH1 3LE, UK

5 College of Science, Department of Geology, University of Sulaimani, Sulaymaniyah 46001, Iraq; diary.amin@univsul.edu.iq

6 Department of Petroleum Geosciences, Faculty of Science, Soran University, Erbil 44008, Iraq; mohammad.askandar@soran.edu.iq

7 Department of Geography, College of Education, University of Garmian, Sulaymaniyah 46021, Iraq; sarkawt.ghazi@garmian.edu.krd

8 Department of Forest Engineering, Santa Catarina State University (UDESC), Lages 88520-000, SC, Brazil; veraldo.liesenberg@udesc.br

* Correspondence: arsalan.aljaf@geosurviraq.iq; Tel.: +964-773-055-2201

Abstract: The increasing world population and the growing quantity of solid waste have become a challenging problem facing governments and policy makers because of the scarcity of suitable sites for new landfills and the negative perception of these sites by the people. This study aims to evaluate the performance of different Multi-Criteria Decision-Analysis (MCDA) approaches using remote sensing and Geographic Information System (GIS) data for identifying suitable landfill sites (LFSs). We evaluated the methodologies used by various investigators and selected appropriate ones as suitable sites for Municipal Solid Waste (MSW) landfill in the Tanjero River Basin (TRB) in the Iraqi Kurdistan region. We applied Boolean Overlay (BO), Weighted Sum Method (WSM), Weighted Product Method (WPM), Analytic Hierarchy Process (AHP), and Technique for Order Performance by Similarity to an Ideal Solution (TOPSIS) to allow combined use of 15 thematic layers as predictive factors (PFs). In this study, we applied the Topographic Position Index (TPI) for the first time to select MSW LFSs. Almost all methods showed reliable results and we identified eight suitable sites situated in the western part of the TRB having total area of $\sim 18.35 \mathrm{~km}^{2}$. The best accuracy was achieved using the AHP approach. This paper emphasizes that the approach of the used method is useful for selecting LFSs in other areas, which are located in similar environments.

Keywords: GIS; landfill; MSW; WSM; WPM; AHP; TOPSIS; MCDA

\section{Introduction}

Waste refers to any substance requiring disposal, which includes unusable materials, worthless, defective and unwanted items. The site of the disposal of waste materials is called landfill. This site involves either collecting, sorting, processing, or recycling of wastes [1-3]. Population has a direct relationship with waste production possesses, which contribute to environmental deterioration [4]. Therefore, for each city, solid waste management is a crucial environmental challenge [5].

Growing world population along with ever-increasing global urbanization has emerged as a major environmental concern in the 21st century. A direct correlation exists between 
population and waste quantity. Urbanites are generating more waste than ever before, as $56.2 \%$ of world population was residing in cities in 2020 . It is estimated that by the middle of this century about $70 \%$ of people in the world will live in cities [6]. In addition, proximity to manufacturing facilities and industrial plants in urban areas contribute to a large amount of waste representing a mix of ordinary garbage, termed Municipal Solid Waste (MSW). Electronic or e-waste, medical/health care waste (that became a serious issue during the COVID-19 pandemic) further adds to the problem of managing the increasing volume of waste [6]. Despite the technological advances in converting waste to energy (WtE) and increasing recycling rates, landfills, as yet, are the predominant way of MSW disposal: For example, in 2019, China accounted for 45\% landfill sites, where China produced more than 242 million tons of MSW [7]. Yet, suitable sites for locating new landfills are getting scarce due to various geological, engineering, legal, and societal constraints. This paper is an attempt to provide a sound basis for landfill site (LFS) selection by using the most widely used criteria and subjecting them to rigorous Geographic Information System (GIS) methodologies. The article is intended to serve as a screening tool to select candidate sites that meet the known criteria to be followed by detailed site investigations. This approach would entail significant cost savings because field studies would be focused on only these promising (candidate) sites that have met the criteria, thereby substantially reducing time and expenses involved in site investigations.

Dozens of studies have been done to solve the waste disposal problem. Part of these studies applied various Multi-Criteria Decision-Analysis (MCDA) models to select suitable location for municipal solid waste (MSW) disposal sites [8]. The most common MCDA models are: fuzzy Analytic Hierarchy Process (AHP) [9], Technique for Order Performance by Similarity to an Ideal Solution (TOPSIS) [10], Weighted Sum Method (WSM) [11], and Weighted Product Method (WPM) [12]. All these methods have been widely used in the field of MSW management [13-18].

A simple review of 27 high quality articles (Table 1) selected from Scopus database and published recently, dealing with landfilling of MSW shows that more than $80 \%$ of these papers used slope gradient, distance to the villages, the towns and the cities, and distance to the road as important predictive factors (PFs) for LFS selection. More than $73 \%$ of these articles applied distance to surface water bodies as a predictive factor (PF), while $>50 \%$ used lithology, soil, land use and land cover (LULC), groundwater depth, and distance to the airport as PFs. Elevation, distance to the active fault, distance to the powerline and distance to the agricultural lands were used less frequently (between 25\% and 50\%).

In this study, we identified suitable sites for LFS using GIS methods and prepared maps showing suitable LFSs for the Tanjero River Basin (TRB) in the Iraqi Kurdistan region. The aims of this paper were twofold: (1) to compare and evaluate the efficacy of five MCDA methods (Boolean Overlay (BO), WSM, WPM, AHP and TOPSIS); and (2) to find the most suitable site(s) for LFS in the TRB. For this purpose, we used 15 layers to assess methods' performance. These thematic layers involve (1) lithology, (2) soil, (3) land cover, (4) distance to road, (5) slope gradient, (6) Topographic Position Index (TPI), (7) groundwater depth, (8) distance to the towns and the cities, (9) distance to the village, (10) distance to the active fault, (11) distance to the powerline, (12) distance to the surface water bodies, (13) distance to the agricultural lands, (14) elevation, and (15) distance to the springs.

Part of the TRB has been studied by [19]. They used MCDA methods to identify seven suitable LFSs. However, we considered the entire TRB to give full evaluation of the whole basin. In addition, we expanded the factors used by [19] via adding some important factors, such as distance to springs, distance to active faults, distance to agricultural lands, and Topographic Position Index (TPI). To the best of our knowledge, the TPI as a PF for LFS selection is being used first time in this study. 
Table 1. Significant factors used for LFS selection in recent articles.
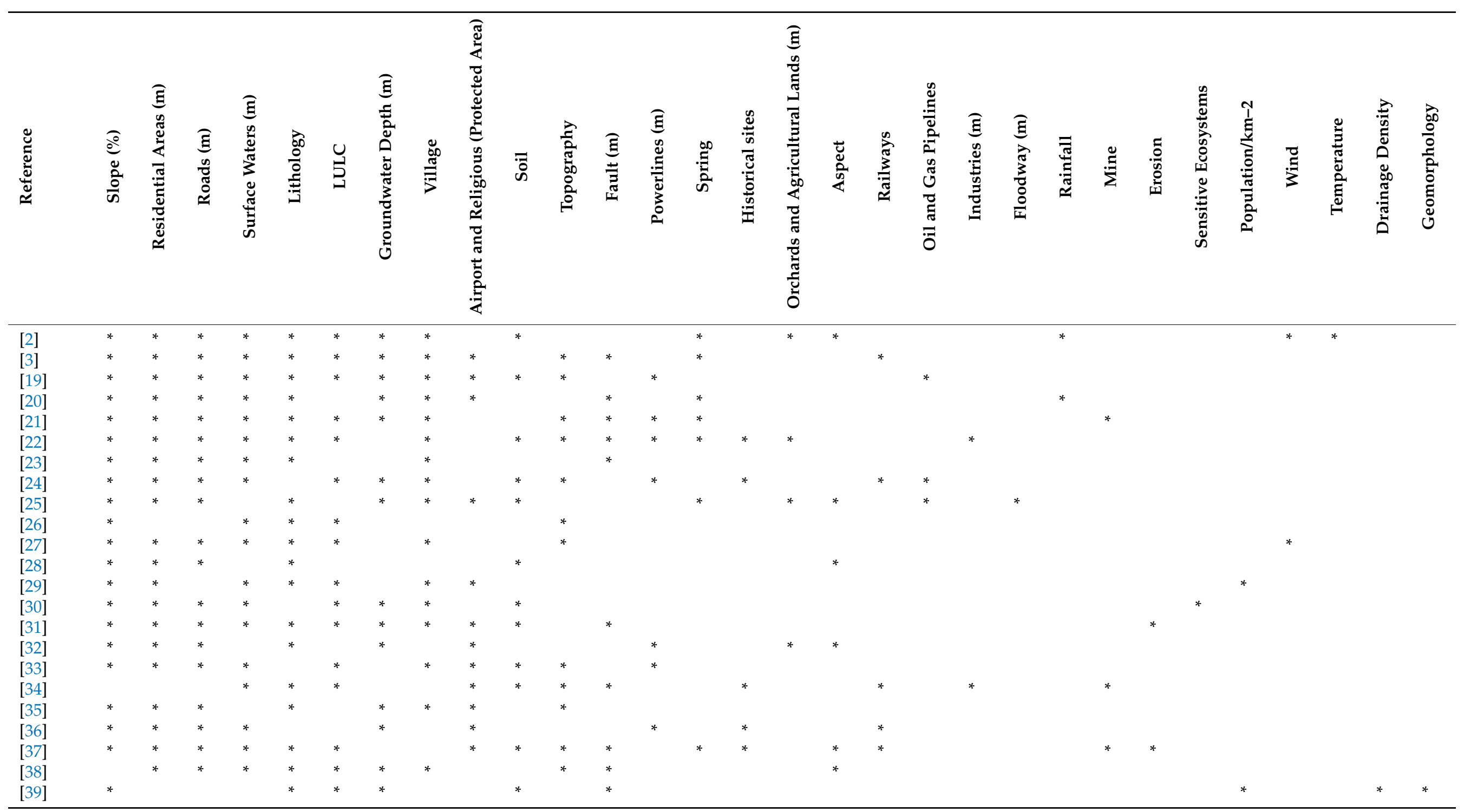
Table 1. Cont.

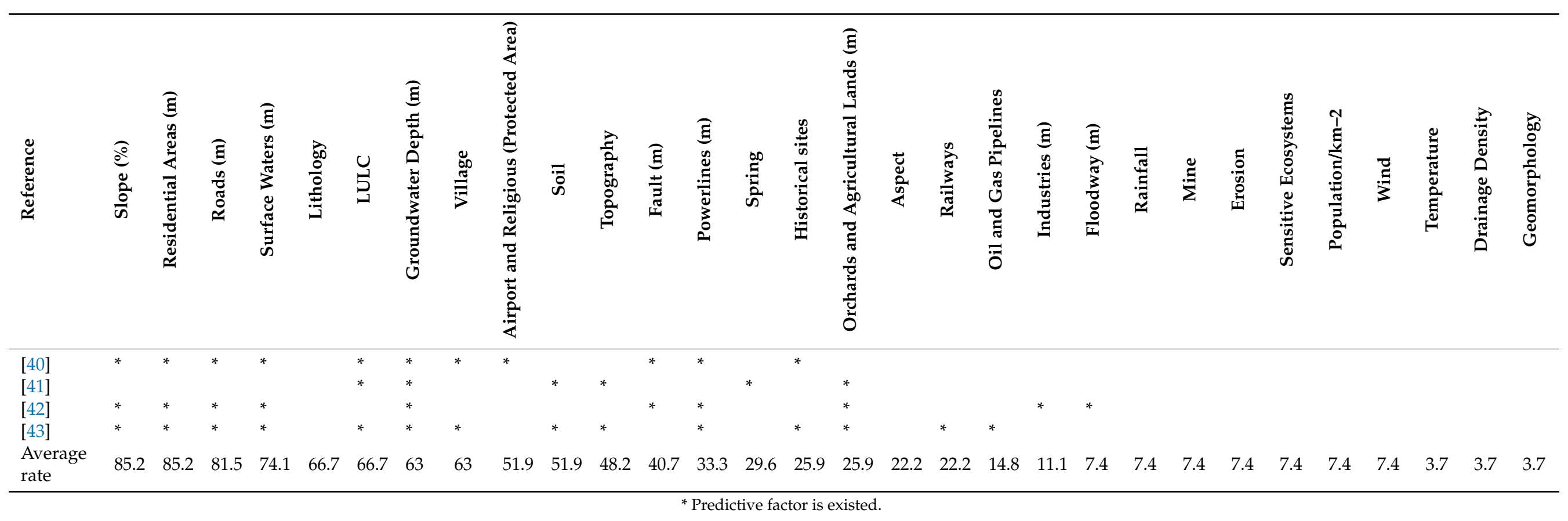




\section{Methodology}

\subsection{Study Area}

The Tanjero River flows northwest, west, and southeast of Sulaymaniyah governorates in the Kurdistan Region between latitude $34^{\circ} 53^{\prime} 34^{\prime \prime} \mathrm{N}$ and $35^{\circ} 47^{\prime} 12^{\prime \prime} \mathrm{N}$, and between longitude $45^{\circ} 11^{\prime} 16^{\prime \prime} \mathrm{E}$ and $46^{\circ} 12^{\prime} 7^{\prime \prime} \mathrm{E}$. The TRB covers $\sim 3317 \mathrm{~km}^{2}$ and encompasses the Sulaymaniyah and Halabja cities and Syed Sadiq town, in addition to Darbandikhan Lake, which is one of the important and main water storages in Iraq (Figure 1). In the last 20 years, the maximum water-level of the Darbandikhan Reservoir was recorded on 27 April 2016 (485.06 $\mathrm{m}$ above sea level (m a.s.l.), while the minimum water-level was recorded on 18 October 2015 (459.49 m a.s.l.) [44]. Tanjero River and its tributaries feed the Darbandikhan Reservoir, which is located in the southwest part of the basin.

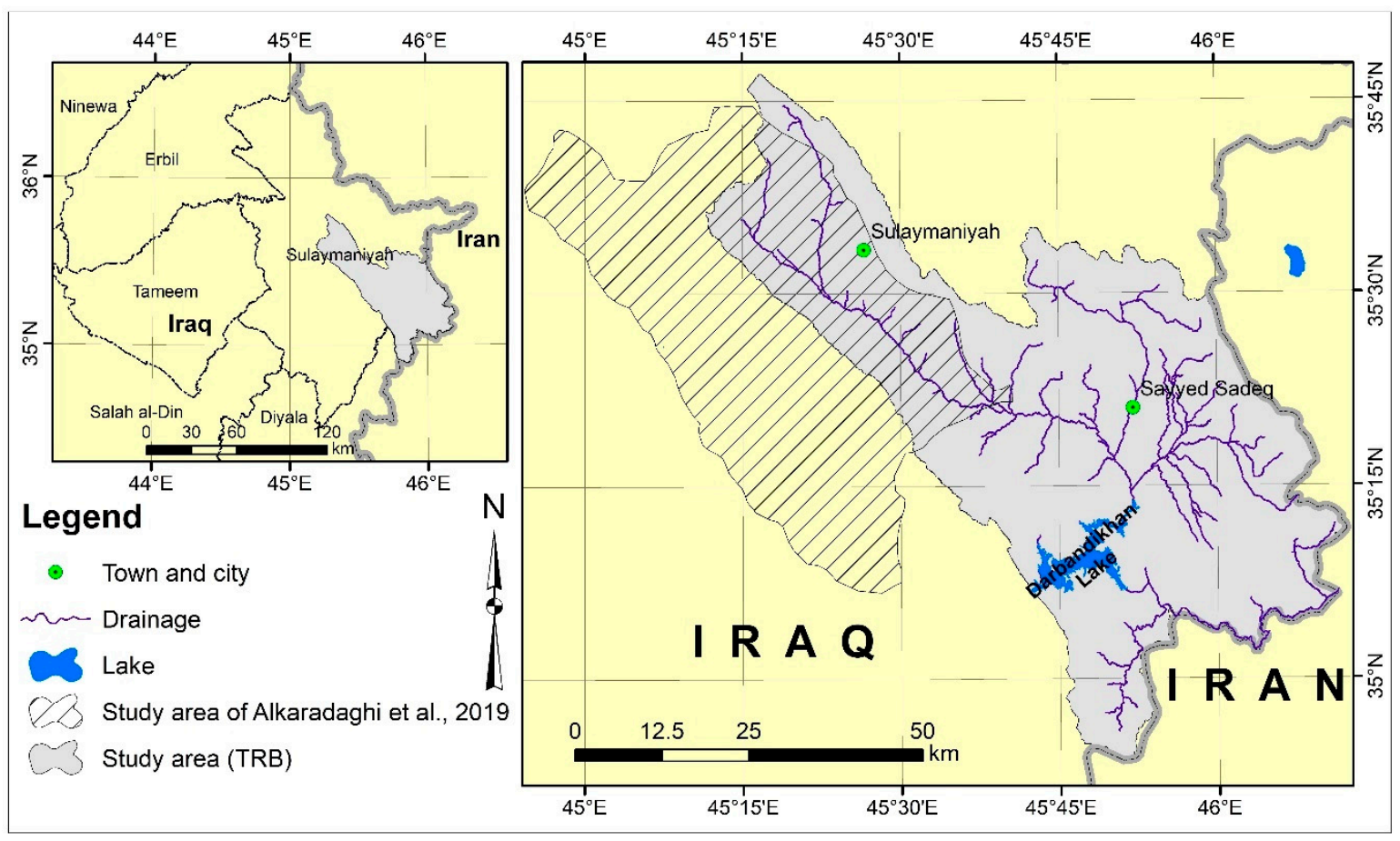

Figure 1. Location map of the Tanjero River Basin [19].

The quantity of MSW generation in Sulaymaniyah City has been increasing rapidly concomitantly with the population's increase, underscoring the need of reliable studies to select suitable LFSs for MSW. According to Iraqi government documents, the population of three major cities, Sulaymaniyah, Halabja and Syed Sadiq on 1 July 2018, was 676,500, 109,000 and 61,600, respectively [45]. However, taking into account residents in over 650 villages within the TRB, the total population will be more than a million. [46] estimated the total volume required to accommodate all municipal waste streams to be generated over the 20 years at 39 million $\mathrm{m}^{3}$ with per capita waste producing $>1.4 \mathrm{~kg}$ per day. This volume needs at least two landfills [46]. Currently, all MSW is being deposited at the Tanjero site, which is located $4.5 \mathrm{~km}$ south of Sulaymaniyah City [47]. Despite co-mingled waste being deposited in an open dump that lacks engineered barriers, leakage and landfill gas management system, Sulaymaniyah government has done its best to make the randomly selected site environmentally safe, despite the lack of financial resources. Nonetheless, the Tanjero dump is unsafe, causing pollution of air, water, and land, and threatening people's health. The problems get worse due to lack of adequate oversight, weakness in the management, monitoring at the site, and weak enforcement of the regulations by responsible parties [48]. It is not only the common urban waste, but wastes from oil refineries, cement plants, along with medical waste from local hospitals are all disposed at the same place [49]. The deficiencies of the existing Tanjero dump and the need of 
environmentally safe LFS are the major drivers of this article to determine suitable sites for new LFS. In addition, the GIS and MCDM methods have not been applied in the larger part of the basin, with the exception of [19] which dealt with the northeast part of the basin.

\subsection{Material}

GIS is a powerful approach due to its capability for processing and analyzing vast data from different sources [1]. The Synthetic Aperture Radar (SAR) was used to identify water bodies, since large areas in the vicinity of the Darbandikhan Reservoir are covered by cloud. We processed one C-band scene of Sentinel 1A/Ground Range Detected High (GRDH) data with instrument mode type of this data, which is the Interferometric Wide Swath (IW). It has $10 \mathrm{~m}$ resolution and Descending orbit pass. This scene was acquired on 27 April 2016 (maximum water-level). Due to frequent cloud coverage on the region before and after 27 April 2016, microwave data were used to penetrate cloud cover. As a first step, we extracted the calibrated backscatter coefficient $(\sigma 0)$, then, converted the linear data to $\log$ scale $(\mathrm{dB})$ data. The $\mathrm{dB}$ data were corrected by applying the Range-Dobbler terrain correction. The maximum water body of the reservoir was determined by thresholding the corrected $\mathrm{dB}$, where the water body has $\mathrm{dB} \leq-20$.

We mosaiced three scenes of Digital Elevation Model (DEM)-Shuttle Radar Topography Mission (SRTM)-with resolution of 1 arc-second $(\sim 30 \mathrm{~m})$. The elevation factor is represented by the DEM, which is also used to extract the slope gradient and the TPI.

SAR data were processed using Sentinel Application Platform (SNAP) software [50]. GIS operations (slope, TPI, distance maps, inverse distance weighted interpolation, and base map), as well as the preparation of final maps, were done using ArcGIS10 [51]. Statistical operations were performed using R-based scripts.

\section{Predictive Factors}

A several of appropriate factors must be taken into account to select the most suitable LFSs. Table 1 shows the 27 reviewed high-quality articles published recently [2,3,20-43]. We depend on these articles to select the PFs dealing with landfilling. Fourteen PFs were selected (Table 2; factors \#1-5 and \#7-15), which were applied $>30 \%$ in the literature, and the rest factors were excluded (Table 1). We used the TPI as a PF (Table 2; factor no. 6) to select MSW landfill sites (LFSs) for the first time.

Table 2. Factors relations towards the LFS selection.

\begin{tabular}{ccccc}
\hline No & Factor & Relationship Type & Type of Data & Relation Intensity \\
\hline 1 & Lithology & No relation & Discrete & Strong \\
2 & Soil & No relation & Discrete & Weak \\
3 & LULC & No relation & Discrete & Weak \\
4 & Distance to road & No relation & Discrete & Weak \\
5 & Slope $\left(^{\circ}\right)$ & No relation & Continuous & Very weak \\
6 & TPI & No relation & Discrete & Strong \\
7 & Direct & Continuous & Strong \\
8 & Croundwater depth $(\mathrm{m})$ & Direct & Continuous & Strong \\
9 & Distance to towns and cities $(\mathrm{m})$ & Direct & Continuous & Moderate \\
10 & Distance to village $(\mathrm{m})$ & Direct & Continuous & Weak \\
11 & Distance to active fault $(\mathrm{m})$ & Direct & Continuous & Very strong \\
12 & Distance to Powerline $(\mathrm{m})$ & Direct & Direct & Weak \\
13 & Distance to surface water bodies $(\mathrm{m})$ & Continuous & Weak \\
14 & Distance to agricultural lands $(\mathrm{m})$ & Co relation & Continuous & Very weak \\
15 & Elevation & Direct & &
\end{tabular}

The PFs used to select the LFSs can be categorized as: hydrologic geologic, topographic, socio-economic and land use factors [20]. We selected fifteen PFs as thematic layers (Table 2). 
The pixel of the layers were resized to $30 \mathrm{~m}$ spatial resolution. Two raster formats were used for the PFs (continuous and discrete; Table 2). We converted the continuous factors to discrete factors by selecting multi threshold values based on our knowledge and background of the study area. The numbers and boundaries of categories can affect the results of the MCDA methods [52]. We classified each continuous PF into five main groups, which are: most suitable, suitable, moderately suitable, less suitable, and not suitable. The classes in the discrete PFs are assigned to have the same five groups (i.e., most suitable, suitable, moderately suitable, less suitable, and not suitable). The weights of the five main groups are 1,3,5,7, and 9, where the not suitable is 1 and the most suitable is 9 .

\subsection{Geological Factors}

Geological factors significantly influence the seepage rate and flow direction of the leakage. Therefore, low permeability geological units were selected to mitigate the contamination risk resulting from the leakage [20]. According to [53], the study area is located within the Unstable Shelf (i.e., Imbricated Zone (IZ), and the High Folded Zone (HFZ)) and the Zagros Suture Zone (ZSZ) of the Zagros orogenic belt. This belt extends approximately $2000 \mathrm{~km}$ long, and trends in NW-SE direction from southern Iran through Iraq to SE Turkey [54-59].

We used the following three geological factors, which are lithological units, distance to active faults, and soil types. (1) Lithological units were obtained by scanning, georeferencing, and digitizing 1:250,000 scale geological quadrangle map of Sulaymaniyah [60] and Khanaqin [61]. The compiled map of the study area includes 21 lithological units (Figure 2A). The ZSZ consists of five units, which consist of limestone, shale, radiolarian cherts, conglomerates, and basalt, ranging in age from Triassic to Late Cretaceous. The Unstable Shelf (USh) includes 11 units. These units mainly include limestone, besides minor amount of dolomite, marl, claystone, shale, conglomerate, siltstones, sandstones, gypsum, and bitumen, were deposited during the Triassic and the Middle Miocene periods. The ZSZ and USh are overlain by five types of Quaternary sediments. The Quaternary sediments include alluvial fans, depression fill, slope debris, and flood plains deposits.

(2) Distance to active faults, where faults are potential pathways for fluid migration and could also be seismically active. Highly faulted areas are not suitable for landfill siting and vice versa [1]; the LFS should be located far from the active faults [62]. We obtained the active faults by digitizing the two series of 1:250,000 scale above mentioned geological maps [60,61]. The TRB includes 148 fault segments. Eight of them are normal faults, while the rest are thrust faults (Figure 2B). The total length of faults is $\sim 161.5 \mathrm{~km}$ but most of them are $<2 \mathrm{~km}$ in length. The major directions of the faults are NNW-SSE and WNW-ESE (Figure 3A). The distance to the faults reaches $34.35 \mathrm{~km}$. Several studies recommended that the landfill could not be located within $500 \mathrm{~m}$ of active faults $[3,38,63,64]$.

(3) Soil types were extracted from the Harmonized World Soil Database (HWSD) [65], which consist of a $1 \mathrm{~km}$ raster image. The LFSs should be located in areas of low permeability soil [66] to prevent water entering the landfill from carrying dissolved polluted materials, causing serious contamination of groundwater system. Three types of soil are occurred in the TRB: leptosols, vertisols, and calcisols (Figure 2C). The leptosols (thin soil with predominantly high infiltration rate) and calcisols (thick soil with predominantly moderately infiltration rate) are loamy soil, while the vertisols is thick light clay soil with predominantly low infiltration rate $[67,68]$ (Figure 3B). 

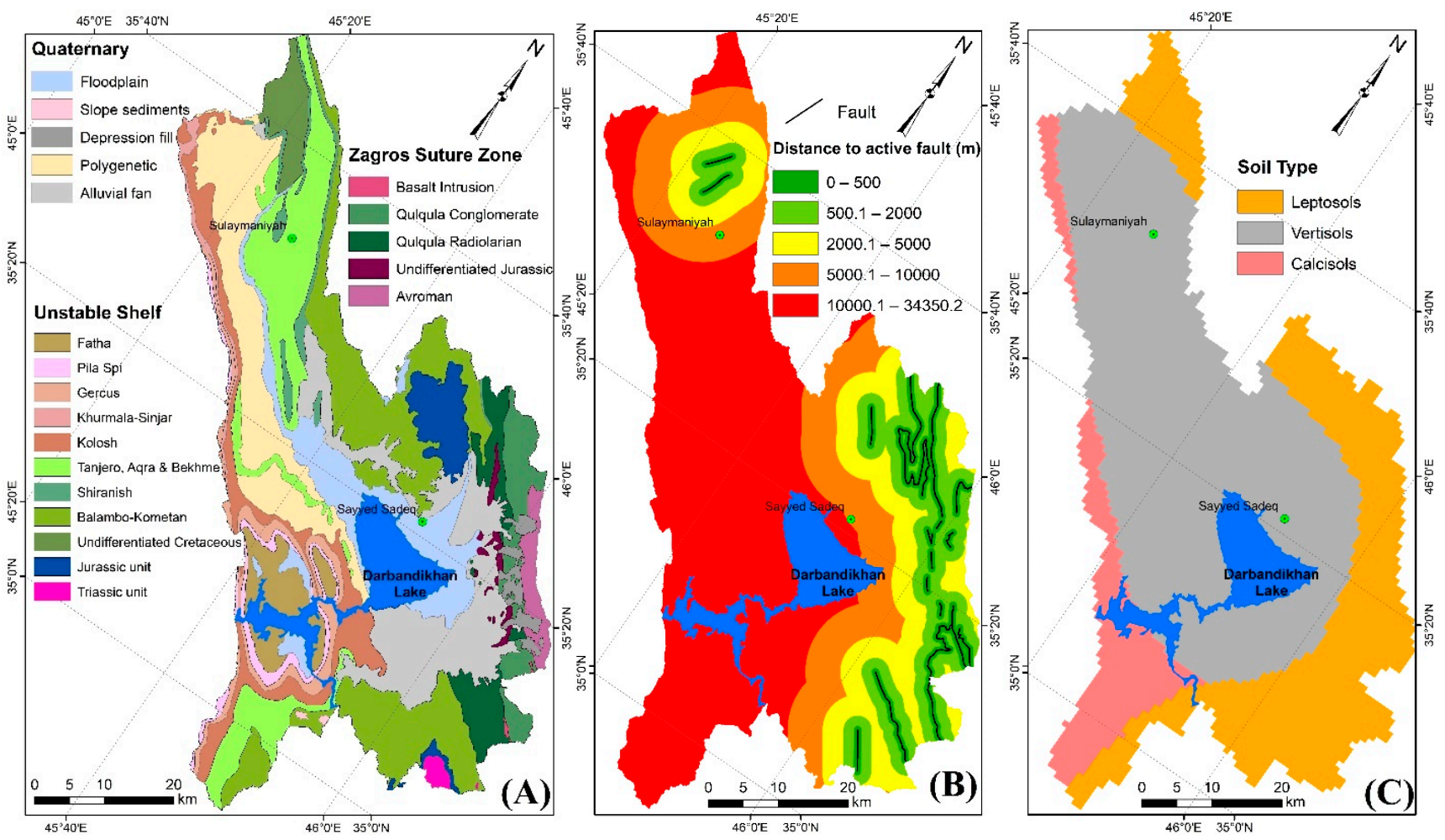

Figure 2. Maps of MSW landfill factors: (A) lithological units [60,61]; (B) distance to faults; (C) soil types [65].
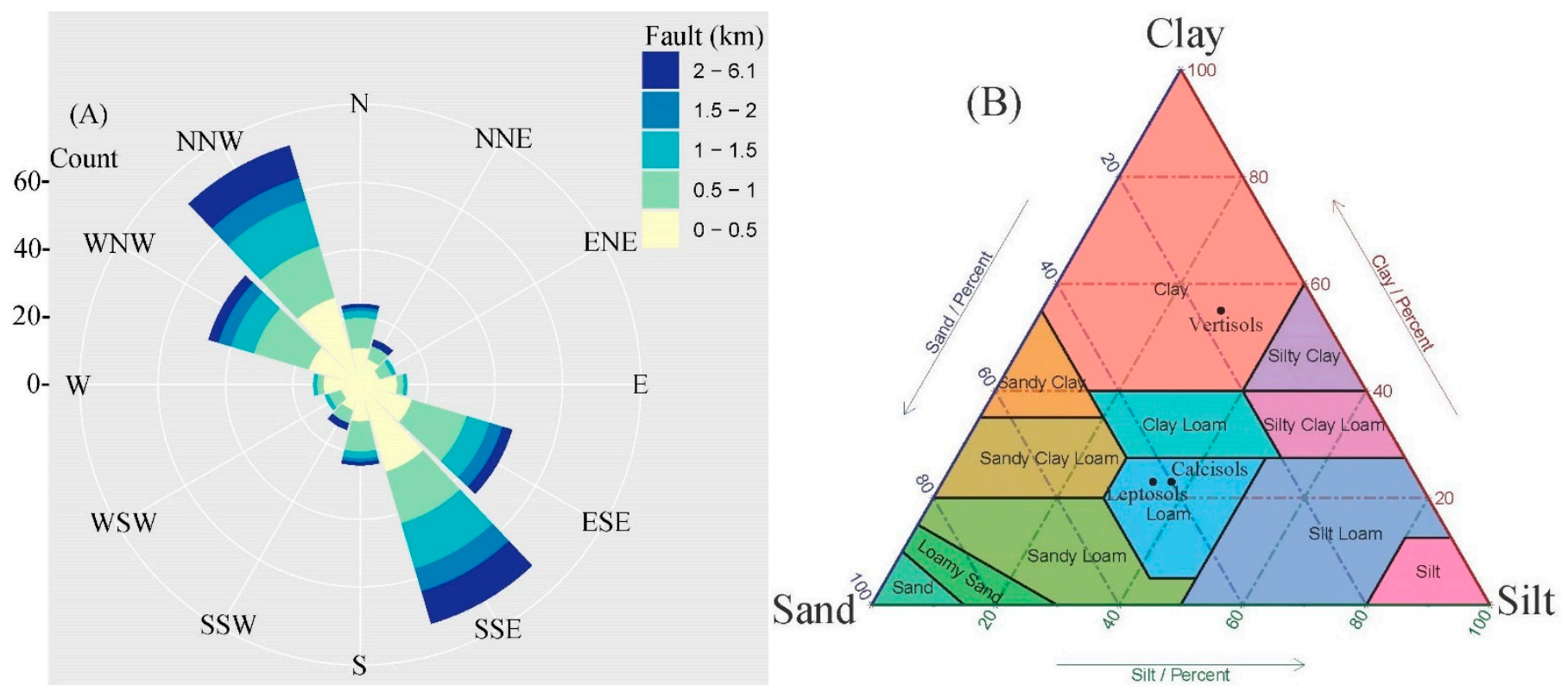

Figure 3. (A) Rose diagram of active faults, and (B) soil textural classification [69] of soil types occurring in the Tanjero River Basin.

\subsection{Topographic (Morphological) Factors}

We used three topographic factors, which are elevation, slope gradient, and Topographic Position Index (TPI).

(1) Elevation factor: high elevation lands are most suitable for LFSs than the low elevation lands in terms of flooding potential [70]. But the drawback is high cost of MSW transportation in the high lands due to high runoff erosion, unstable slopes cuts for roads, all requiring frequent maintenance [71]. In addition, the high lands maybe represent 
groundwater recharge zones [72]. The range of elevation in TRB is between 423 and $2615 \mathrm{~m}$ (Figure 4A). The highest suitability rank is assigned to moderate elevation lands (Table 3 ).
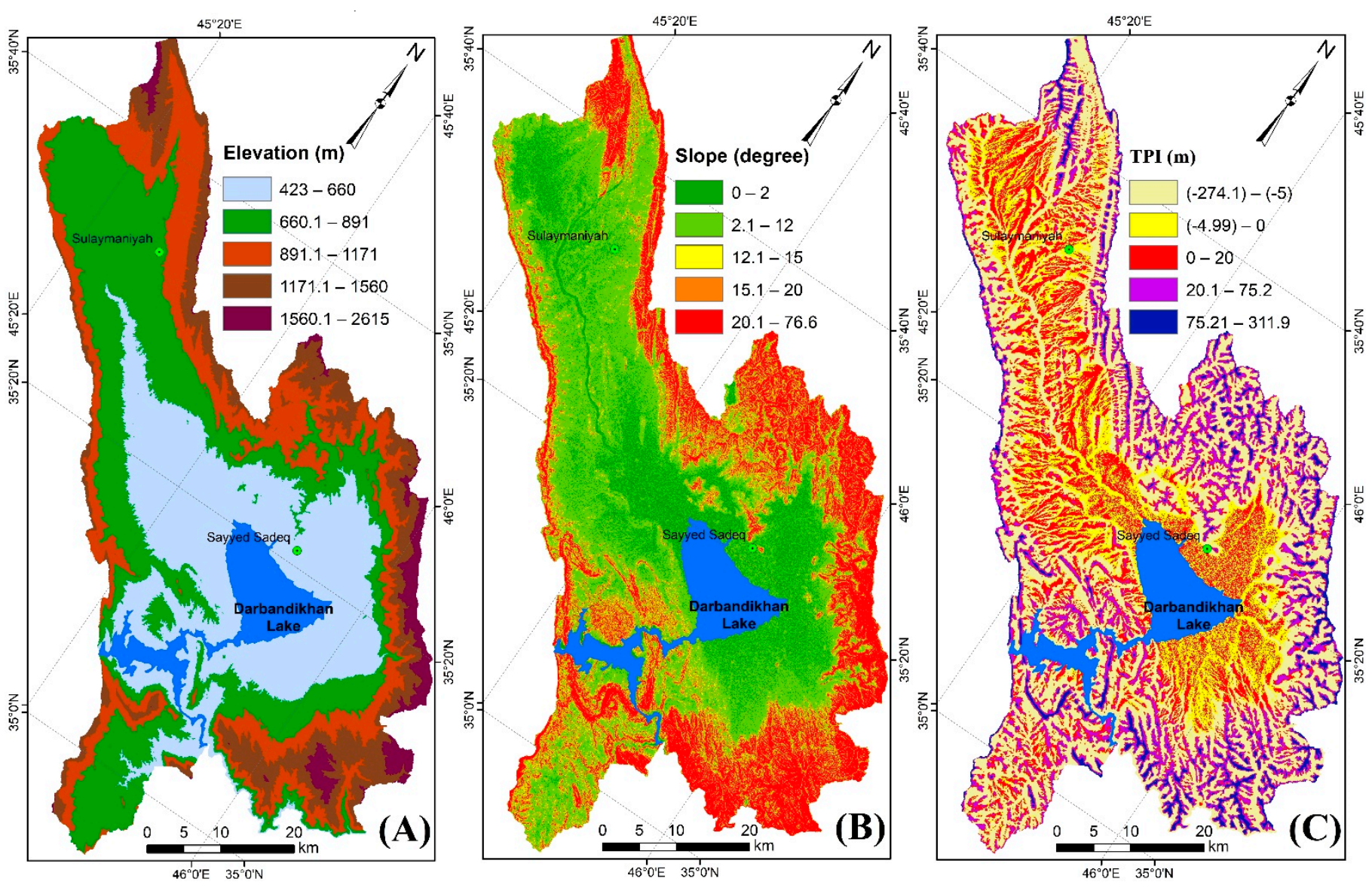

Figure 4. Maps of the landfill factors: (A) Elevation, (B) Slope gradient, and (C) Topographic Position Index (TPI).

(2) Slope gradient data were extracted from DEM. The significance of the slope gradient is in evaluating the stability of slopes and landslide potential and road failures for construction and operation of landfill. Lands having gentle slopes are more suitable than lands with a steep slope for landfill siting [71]. The pixels with slope $>20^{\circ}$ are unsuitable for MSW landfill [8]. Slope gradients in TRB range between flat and $76.6^{\circ}$ (Figure 4B). We determined the slope gradient pixels in the $2^{\circ}-12^{\circ}[3,73]$ and $12.1^{\circ}-15^{\circ}$ range to be most suitable for landfill location. The horizontal, steep, and very steep slopes areas are moderate, less suitable, and not suitable sites, respectively (Table 3).

(3) TPI, as a PF for landfill, is calculated using Equation (1) [74], which calculates the fluctuation between the pixel elevation and the surrounded pixels average elevation using a pre-specific kernel-matrix $(M)$.

$$
T P I=E_{c}-\left(\frac{1}{n M} \sum_{i \in m} E_{i}\right)
$$

There is a relationship between the slope curvature and water infiltration to the groundwater where water infiltration increases with the concave up and decreases with the concave down. However, the slope curvature function considers a few pixels around the central point of the used Kernel (three by three pixels) [75], which exhibits higher errors in terms of the occurrence of local depressions. Thus, some areas seem to be locally suitable for landfilling while, in fact, it is unsuitable for large-scale LFS selection. To overcome this challenge and propose more accurate sites to be used as landfilling, we proposed the use of TPI, which considers larger area and avoid local curvature. 
Table 3. Decision rules for used PFs and finalized weights of factors acquired from WSM, SPM, AHP models.

\begin{tabular}{|c|c|c|c|c|c|c|c|}
\hline Lithology & Suitability & Rank & $\begin{array}{c}\text { Normalized } \\
\text { Weight }\end{array}$ & $\begin{array}{l}\text { Groundwater } \\
\text { Depth (m) }\end{array}$ & Suitability & Rank & $\begin{array}{c}\text { Normalized } \\
\text { Weight }\end{array}$ \\
\hline Lake & Not suitable & 1 & 0.00317 & $0-13$ & Not suitable & 1 & 0.003623 \\
\hline Floodplain & Not suitable & 1 & 0.00317 & $13.1-30$ & Less suitable & 3 & 0.01087 \\
\hline Slope sediments & Not suitable & 1 & 0.00317 & $30.1-48$ & $\begin{array}{l}\text { Moderately } \\
\text { suitable }\end{array}$ & 5 & 0.018116 \\
\hline Depression fill & Not suitable & 1 & 0.00317 & $48.1-80$ & Suitable & 7 & 0.025362 \\
\hline $\begin{array}{l}\text { Polygenetic } \\
\text { sediments }\end{array}$ & Not suitable & 1 & 0.00317 & $80.1-159.38$ & Most suitable & 9 & 0.032609 \\
\hline Alluvial fan & Not suitable & 1 & 0.00317 & $\begin{array}{l}\text { Distance to } \\
\text { Towns and } \\
\text { Cities (m) }\end{array}$ & Suitability & Rank & $\begin{array}{c}\text { Normalized } \\
\text { Weight }\end{array}$ \\
\hline $\begin{array}{l}\text { Avroman } \\
\text { limestone }\end{array}$ & Less suitable & 3 & 0.009511 & 0-1000 & Not suitable & 1 & 0.00317 \\
\hline $\begin{array}{c}\text { Undifferentiated } \\
\text { Jurassic }\end{array}$ & $\begin{array}{l}\text { Moderately } \\
\text { suitable }\end{array}$ & 5 & 0.015851 & $1000.1-5000$ & Less suitable & 3 & 0.009511 \\
\hline $\begin{array}{l}\text { Qulqula } \\
\text { radiolarian }\end{array}$ & Not suitable & 1 & 0.00317 & $5000.1-10,000$ & $\begin{array}{l}\text { Moderately } \\
\text { suitable }\end{array}$ & 5 & 0.015851 \\
\hline $\begin{array}{c}\text { Qulqula } \\
\text { conglomerate }\end{array}$ & Less suitable & 3 & 0.009511 & $10,000.1-20,000$ & Suitable & 7 & 0.022192 \\
\hline Basalt intrusion & Most suitable & 9 & 0.028533 & $20,000.1-14,725.7$ & Most suitable & 9 & 0.028533 \\
\hline Fatha & Most suitable & 9 & 0.028533 & $\begin{array}{l}\text { Distance to } \\
\text { Village (m) }\end{array}$ & Suitability & Rank & $\begin{array}{c}\text { Normalized } \\
\text { Weight }\end{array}$ \\
\hline Pila Spi & Less suitable & 3 & 0.009511 & $0-1000$ & Not suitable & 1 & 0.00317 \\
\hline Gercus & Most suitable & 9 & 0.028533 & 1000.1-2000 & Less suitable & 3 & 0.009511 \\
\hline Khurmala-Sinjar & Less suitable & 3 & 0.009511 & 2000.1-3000 & $\begin{array}{l}\text { Moderately } \\
\text { suitable }\end{array}$ & 5 & 0.015851 \\
\hline Kolosh & Suitable & 7 & 0.022192 & $3000.1-4000$ & Suitable & 7 & 0.022192 \\
\hline $\begin{array}{l}\text { Tanjero, Aqra } \\
\text { and Bekhme }\end{array}$ & Less suitable & 3 & 0.009511 & $4000.1-5768.3$ & Most suitable & 9 & 0.028533 \\
\hline Shiranish & Suitable & 7 & 0.022192 & $\begin{array}{c}\text { Distance to } \\
\text { Active Fault (m) }\end{array}$ & Suitability & Rank & $\begin{array}{c}\text { Normalized } \\
\text { Weight }\end{array}$ \\
\hline $\begin{array}{l}\text { Balambo- } \\
\text { Kometan }\end{array}$ & Less suitable & 3 & 0.009511 & $0-500$ & Not suitable & 1 & 0.002264 \\
\hline $\begin{array}{c}\text { Undifferentiated } \\
\text { Cretaceous }\end{array}$ & Less suitable & 3 & 0.009511 & 50.1-2000 & Less suitable & 3 & 0.006793 \\
\hline Jurassic & Less Suitable & 3 & 0.009511 & $2000.1-5000$ & $\begin{array}{l}\text { Moderately } \\
\text { suitable }\end{array}$ & 5 & 0.011322 \\
\hline Triassic & Less suitable & 3 & 0.009511 & 5000.1-10,000 & Suitable & 7 & 0.015851 \\
\hline Soil & Suitability & Rank & $\begin{array}{l}\text { Normalized } \\
\text { Weight }\end{array}$ & $10,000.1-34,350.2$ & Most suitable & 9 & 0.02038 \\
\hline Leptosols & Less suitable & 3 & 0.004076 & $\begin{array}{c}\text { Distance to } \\
\text { Powerline (m) }\end{array}$ & Suitability & Rank & $\begin{array}{c}\text { Normalized } \\
\text { Weight }\end{array}$ \\
\hline Vertisols & Suitable & 7 & 0.009511 & $0-300$ & Not suitable & 1 & 0.001359 \\
\hline Calcisols & $\begin{array}{l}\text { Moderately } \\
\text { suitable }\end{array}$ & 5 & 0.006793 & $300.1-5000$ & Less suitable & 3 & 0.004076 \\
\hline
\end{tabular}


Table 3. Cont.

\begin{tabular}{|c|c|c|c|c|c|c|c|}
\hline Lithology & Suitability & Rank & $\begin{array}{c}\text { Normalized } \\
\text { Weight }\end{array}$ & $\begin{array}{l}\text { Groundwater } \\
\text { Depth (m) }\end{array}$ & Suitability & Rank & $\begin{array}{c}\text { Normalized } \\
\text { Weight }\end{array}$ \\
\hline LULC & Suitability & Rank & $\begin{array}{c}\text { Normalized } \\
\text { Weight }\end{array}$ & 5000.1-10,000 & $\begin{array}{l}\text { Moderately } \\
\text { suitable }\end{array}$ & 5 & 0.006793 \\
\hline Water bodies & Not suitable & 1 & 0.001812 & $10,000.1-20,000$ & Suitable & 7 & 0.009511 \\
\hline $\begin{array}{l}\text { Urban and } \\
\text { built-up land }\end{array}$ & Not suitable & 1 & 0.001812 & $20000.1-40,864.9$ & Most suitable & 9 & 0.012228 \\
\hline Vegetated land & Less suitable & 3 & 0.005435 & $\begin{array}{l}\text { Distance to } \\
\text { Surface Water } \\
\text { Bodies (m) }\end{array}$ & Suitability & Rank & $\begin{array}{c}\text { Normalized } \\
\text { Weight }\end{array}$ \\
\hline Harvested land & Less suitable & 3 & 0.005435 & $0-500$ & Not suitable & 1 & 0.004076 \\
\hline Cultivated land & Less suitable & 3 & 0.005435 & $500.1-5000$ & Less suitable & 3 & 0.012228 \\
\hline Carbonate rocks & Suitable & 7 & 0.012681 & $5000.1-10,000$ & $\begin{array}{c}\text { Moderately } \\
\text { suitable }\end{array}$ & 5 & 0.02038 \\
\hline Clastics rocks & Most suitable & 9 & 0.016304 & $10,000.1-30,000$ & Suitable & 7 & 0.028533 \\
\hline Burn land & $\begin{array}{l}\text { Moderately } \\
\text { suitable }\end{array}$ & 5 & 0.009058 & $30,000.1-59,722.4$ & Most suitable & 9 & 0.036685 \\
\hline $\begin{array}{l}\text { Distance to } \\
\text { Road (m) }\end{array}$ & Suitability & Rank & $\begin{array}{c}\text { Normalized } \\
\text { Weight }\end{array}$ & $\begin{array}{l}\text { Distance to } \\
\text { Agricultural } \\
\text { Lands (m) }\end{array}$ & Suitability & Rank & $\begin{array}{c}\text { Normalized } \\
\text { Weight }\end{array}$ \\
\hline $0-1000$ & Not suitable & 1 & 0.001359 & $0-300$ & Not suitable & 1 & 0.000906 \\
\hline $1000.1-5000$ & Most suitable & 9 & 0.012228 & $300.1-600$ & Less suitable & 3 & 0.002717 \\
\hline 5000.1-10000 & Suitable & 7 & 0.009511 & $600.1-1200$ & $\begin{array}{l}\text { Moderately } \\
\text { suitable }\end{array}$ & 5 & 0.004529 \\
\hline 10000.1-20000 & $\begin{array}{l}\text { Moderately } \\
\text { suitable }\end{array}$ & 5 & 0.006793 & $1200.1-2500$ & Suitable & 7 & 0.006341 \\
\hline$>10000$ & Less suitable & 3 & 0.004076 & $2500.1-4183.4$ & Most suitable & 9 & 0.008152 \\
\hline Slope $\left({ }^{\circ}\right)$ & Suitability & Rank & $\begin{array}{c}\text { Normalized } \\
\text { Weight }\end{array}$ & Elevation (m) & Suitability & Rank & $\begin{array}{c}\text { Normalized } \\
\text { Weight }\end{array}$ \\
\hline$>20$ & Not suitable & 1 & 0.001359 & $1560.1-2615$ & Not suitable & 1 & 0.000906 \\
\hline $15.1-20$ & Less suitable & 3 & 0.004076 & 1171.1-1560 & $\begin{array}{l}\text { Moderately } \\
\text { suitable }\end{array}$ & 5 & 0.004529 \\
\hline $12.1-15$ & Suitable & 7 & 0.009511 & 891.1-1171 & Suitable & 7 & 0.006341 \\
\hline $2-12$ & Most suitable & 9 & 0.012228 & $660.1-891$ & Most Suitable & 9 & 0.008152 \\
\hline $0-2$ & $\begin{array}{l}\text { Moderately } \\
\text { suitable }\end{array}$ & 5 & 0.006793 & $423-660$ & Less suitable & 3 & 0.002717 \\
\hline TPI (m) & Suitability & Rank & $\begin{array}{c}\text { Normalized } \\
\text { Weight }\end{array}$ & $\begin{array}{l}\text { Distance to } \\
\text { Springs }\end{array}$ & Suitability & Rank & $\begin{array}{c}\text { Normalized } \\
\text { Weight }\end{array}$ \\
\hline$(-274.1)-(-5)$ & Not suitable & 1 & 0.000453 & $0-500$ & Not suitable & 1 & 0.004076 \\
\hline$(-4.99)-0$ & Less suitable & 3 & 0.001359 & 500.1-1000 & Less suitable & 3 & 0.012228 \\
\hline $0-20$ & $\begin{array}{l}\text { Moderately } \\
\text { suitable }\end{array}$ & 5 & 0.002264 & $1000.1-5000$ & $\begin{array}{c}\text { Moderately } \\
\text { suitable }\end{array}$ & 5 & 0.02038 \\
\hline $20.1-75.2$ & Most suitable & 9 & 0.004076 & $5000.1-15,000$ & Suitable & 7 & 0.028533 \\
\hline $75.21-311.9$ & Suitable & 7 & 0.00317 & $15,000.1-28,909.1$ & Most suitable & 9 & 0.036685 \\
\hline
\end{tabular}

Negative TPI means that the central pixel has elevation lower than the average surroundings pixels, while positive TPI means that the central pixel has an elevation higher than the average surroundings pixels [52]. We computed TPI for the study area in ArcGIS 
software using a moving window of 50 pixels [52]. The range of TPI in TRB is between -274.1 and $311.9 \mathrm{~m}$ (Figure 4C). The highest rank of suitability is assigned to the areas within moderate topographic positions (i.e., 20.1-75.2 m; Table 3).

\subsection{Hydrogeological and Hydrological Factors}

MSW landfills are a significant cause of groundwater pollution, so the depth to groundwater surface at a LFS is a very critical. The depth to groundwater in the study area is more than $10 \mathrm{~m}$, which is suitable for landfilling [76]. The available data of 243 boreholes obtained from Sulaymaniyah Groundwater Directorate is used [77] to generate depth to groundwater map, the depth ranges between 0 to $159.4 \mathrm{~m}$ (Figure 5A). In addition, data of surface water and springs (which will be mentioned below) as a zero-groundwater level are used. The groundwater in TRB classified as a fresh water [78], the TDS content varies between $<500$ to $900 \mathrm{mg} / \mathrm{L}$. Previous studies, such as [19,79-84], have revealed that the ground and surface waters in the area are polluted with many organic and inorganic contaminants, and the problem is getting worse due to the prevailing draught condition in the area.
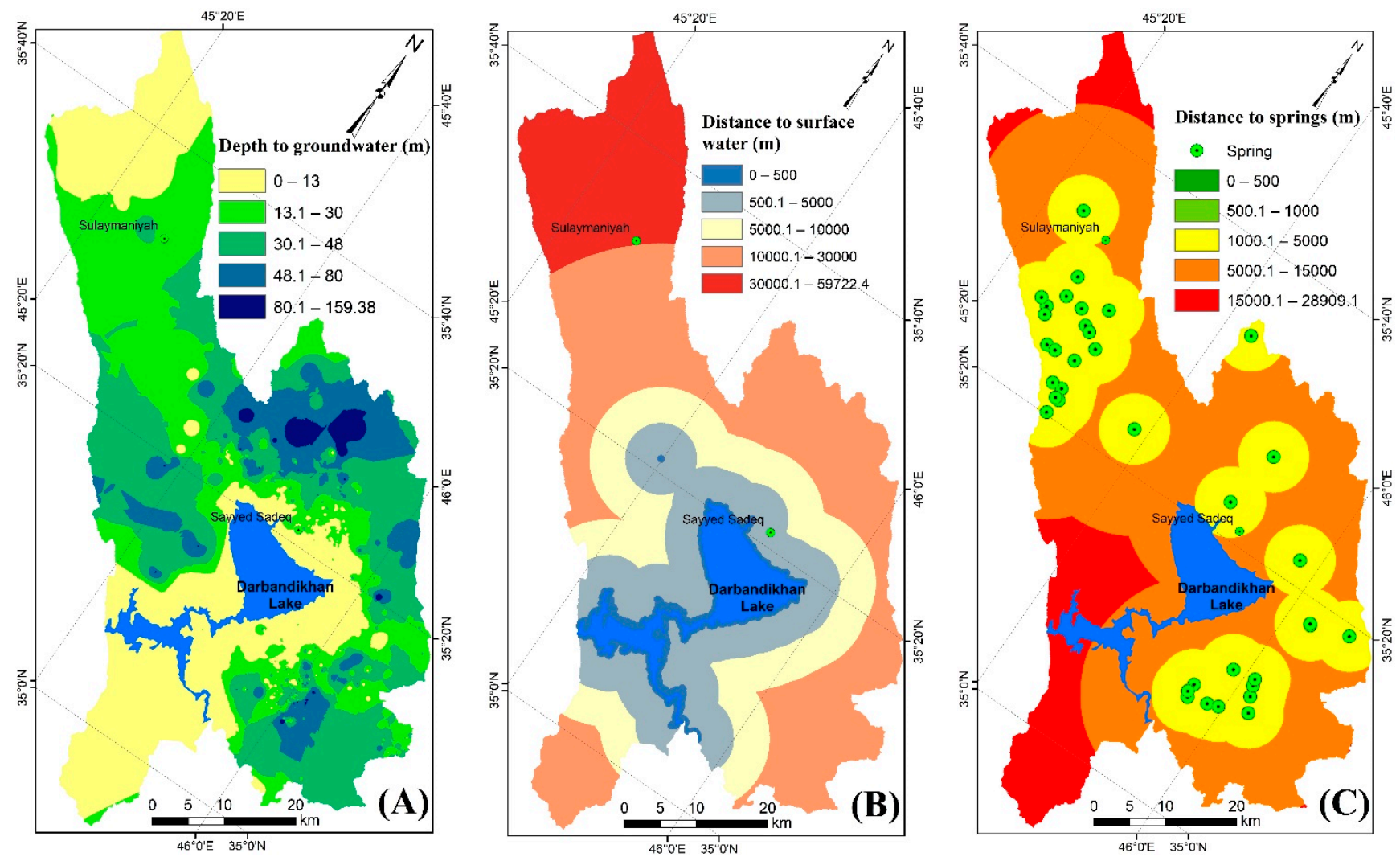

Figure 5. Maps of MSW landfill factors: (A) depth to groundwater, (B) distance to surface water, and (C) distance to springs.

Water bodies and surrounding areas cannot be used as sites for MSW LFS due to high potential of direct contamination. $[3,38,85]$ stated that $500 \mathrm{~m}$ distance around the surface water is a fair buffer, while [76] thought that the buffer zone should be $>5000 \mathrm{~m}$. Both the Darbandikhan Lake (with an area of $66.86 \mathrm{~km}^{2}$ ) and the Tanjero River, located in the TRB, contain potable water with the TDS varying from 271 to $412 \mathrm{ppm}$, respectively [86]. The distance to water bodies is up to $59.7 \mathrm{~km}$ (Figure 5B), with water level of $485.06 \mathrm{~m}$ a.s.l.; [87]).

Distance to springs is produced using 37 springs acquired from Sulaymaniyah Surface Water Directorate [87]. According to [3,88], a minimum buffer of $300 \mathrm{~m}$ must be used around springs to determine MSW LFSs, while $[70,89]$ stated that a MSW landfill should not be sited $<500 \mathrm{~m}$. The distance to springs areas in TRB reaches $28.9 \mathrm{~km}$ (Figure 5C). 


\subsection{Socio-Economic Factors}

This factor is included to evaluate potential impacts from landfill siting and to minimize economic and aesthetic deterioration. We used four socio-economic factors, which are: distance to towns and cities $(\mathrm{m})$, distance to villages $(\mathrm{m})$, distance to roads $(\mathrm{m})$, and distance to powerlines (m). The MSW landfill must be located at a reasonable distance far from villages, towns, and cities due to health and public concerns [66]. [3,88] reported appropriate distance of the landfill from villages, towns, and cities to be $>1000 \mathrm{~m}$. In the TRB, the farthest pixel from cities and towns is $\sim 14.7 \mathrm{~km}$ away (Figure $6 \mathrm{~A}$ ), while the farthest pixel from villages is $\sim 5.7 \mathrm{~km}$ (Figure $6 \mathrm{~B}$ ).
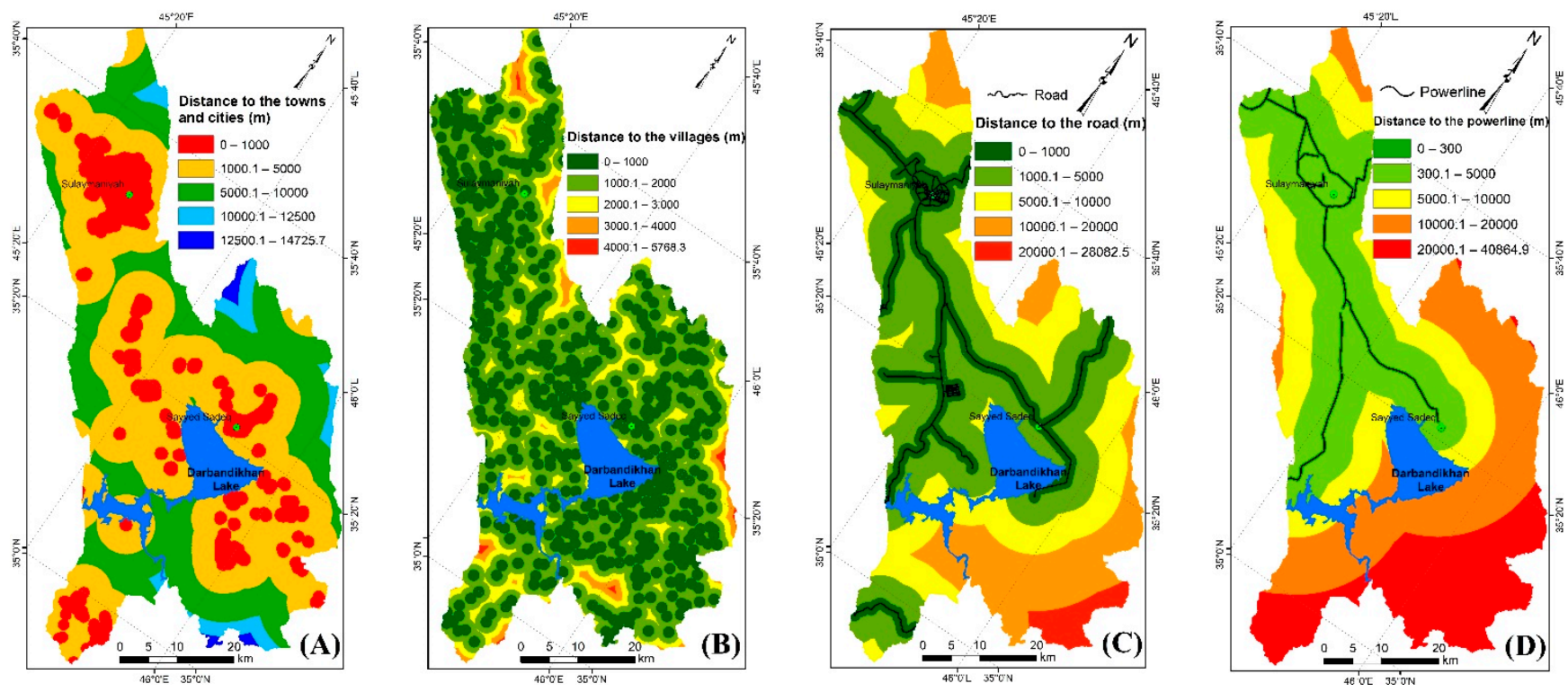

Figure 6. Maps of MSW landfill factors: (A) distance to the towns and cities, (B) distance to the village, (C) distance to the road, and (D) distance to the powerline.

LFSs should be selected to be at a justifiable distance away from the roads to avoid negative aesthetic impacts [24]. The researcher used different values as minimum distance to the road (m) for selecting the MSW landfill. They proposed $300 \mathrm{~m}[30,38], 500 \mathrm{~m}[36,37]$, and $1000 \mathrm{~m}[66,90]$ as buffer distance from MSW landfill. Accordingly, we eliminated sites within $1000 \mathrm{~m}$ of major roads. We believe that it will provide adequate buffer zone for noise, dust, etc. created from movement of garbage trucks, without requiring construction of new access roads for transportation and collection of solid wastes [22,27]. The farthest point from roads in the TRB is $\sim 28.1 \mathrm{~km}$ (Figure $6 \mathrm{C}$ ).

As [36] suggested, we used a buffer $300 \mathrm{~m}$ (4) distance to the powerline (m) as nonsuitable areas for MSW LFSs. The farthest area from powerlines in the TRB is $\sim 41 \mathrm{~km}$ (Figure 6D). The shapefiles of the settlements, the roads and powerlines were obtained from [91]. We calculated the Euclidean distances from existing villages, towns, cities, roads, and powerlines minimum distances from these features to each pixel in the TRB.

\subsection{Land Use Factors}

We used two land use PFs: (1) land use and land cover (LULC), and (2) distance to agricultural lands.

(1) The LULC map was supplied by Iraq Geological Survey and contains nine classes (Figure 7A). It was produced using Landsat satellite data having $30 \mathrm{~m}$ spatial resolution. It has been validated by fieldtrip with an overall accuracy of $\sim 93.60 \%$ [92]. Several land covers are present in the study area and include: water bodies, urban and built-up land, vegetated land, harvested land, cultivated land, burnt land, carbonate rocks, conglomerates and gravels, and other clastic rocks [92]. 

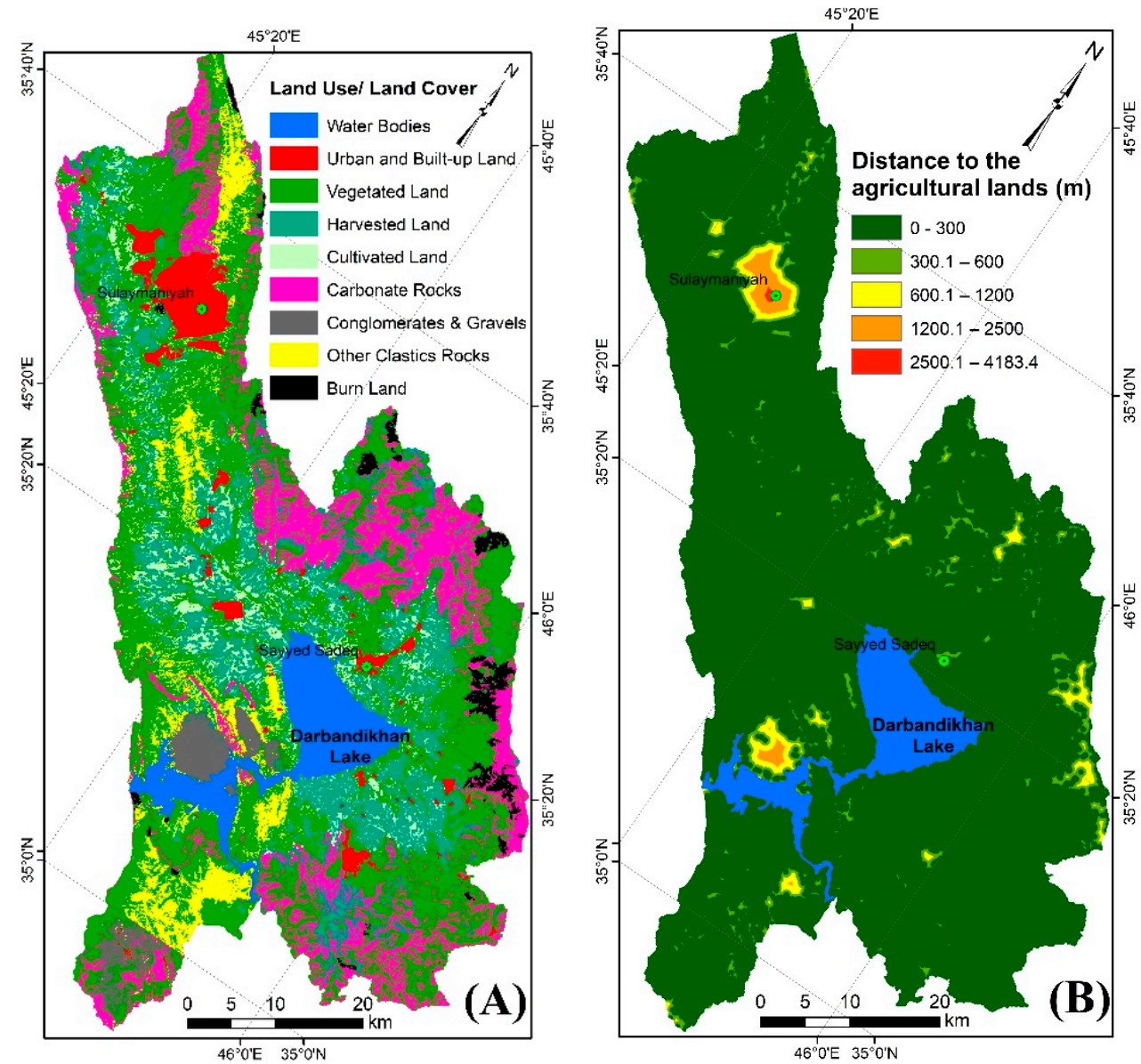

Figure 7. Maps of MSW landfill factors: (A) land use and land cover (LULC), and (B) distance to agricultural lands.

(2) The area under forest cover must be avoided for landfill siting because it negatively affects natural forest resources [93]. We used distance to agricultural lands (m) to avoid selecting landfill in and near the vegetation cover. We calculated the Euclidean distances from vegetation cover distances within TRB (Figure 7B). The Normalized Difference Vegetation Index (NDVI) was used to characterize the vegetation cover. We used the equation proposed by [94] to calculate the NDVI. It was calculated after extraction of the reflectance ( $\rho$ ) from the digital number (DN) of Landsat data [38]. proposed that $300 \mathrm{~m}$ distance away from agricultural and forest lands could be acceptable for locating MSW landfill.

\section{Suitable Landfill Site Selection Model}

There is no agreement about a specific method that can be considered to be the most suitable for all types of decision-making technique [95-97]. A big criticism of MCDM is the fact that various methods might obtain various results if used to the same issue [98]. The definition of a suitable MCDM approach is thus not a simple task, and the focus should be on the precise determination of the approach [95]. Available papers show huge practical applications of comparative analyses of various MCDM approaches [9,11-18,99]. We employed five methods to distinguish suitable locations for MSW LFSs. These methods are BO, WSM, WPM, TOPSIS, and AHP.

\subsection{Boolean Overlay (BO)}

$\mathrm{BO}$ is a simple method, widely used to determine suitable sites for solid waste landfills $[2,16,17,31,37,38,100-103]$. It is based on reclassifying multi-factors used to select LFSs into binary values $(0,1)$, where 1 and 0 are suitable (yes) and unsuitable (no) pixels, respectively [31]. We prepared a final suitability map for landfilling by combining whole-created 
binary maps for the constraints using the Boolean overlay (AND operation), which is defined by Equation (2) [17]:

$$
1=\{\text { if } \mathrm{A}>\mathrm{X} \geq \mathrm{B}\}, \mathrm{OR} 0
$$

where $\mathrm{A}$ and $\mathrm{B}$ are constant, and $\mathrm{X}$ is the factor

To be on the safe side for LFS selection, we used the maximum distance for various factors (Table 4).

Table 4. Safe distance of Boolean conditions.

\begin{tabular}{ccc}
\hline Factor & Threshold & Reference \\
\hline Lithology & $*$ & $/$ \\
Soil & $* *$ & $/$ \\
LULC & $* * *$ & $/$ \\
Distance to main roads $(\mathrm{m})$ & 1000 & {$[66,90]$} \\
Slope $\left(^{\circ}\right)$ & $>20$ & $/$ \\
TPI $(\mathrm{m})$ & $<-5$ & {$[8]$} \\
Groundwater depth $(\mathrm{m})$ & 13 & {$[3,]^{\#}$} \\
Distance to villages, city and towns $(\mathrm{m})$ & 1000 & {$[3,38,63,64]$} \\
Distance to active faults $(\mathrm{m})$ & 500 & {$[36]$} \\
Distance to Powerline $(\mathrm{m})$ & 300 & {$[3,38,85]$} \\
Distance to surface water bodies $(\mathrm{m})$ & 500 & {$[38]$} \\
Distance to agricultural lands $(\mathrm{m})$ & 300 & $/$ \\
Elevation & $>1560$ & {$[70,89]$} \\
Distance to spring & 500 &
\end{tabular}

* Qulqula radiolarian, Lake, and all Quaternary sediments (i.e., floodplain, slope sediments, depression fill, polygenetic sediments, and alluvial fan) is nominated as not suitable for LFS selection. ${ }^{* *}$ No soil classes have been nominated as not suitable for LFS selection. ${ }^{* * *}$ Water bodies, and urban and built-up land have been nominated as not suitable for LFS selection" Abd-El Monsef and Smith (2019) used minimum groundwater depth of $10 \mathrm{~m}$.

\subsection{Weighted Sum Method (WSM)}

WSM is a straightforward MCDM method, used for solid waste LFS selection [37, 104-106]. This method considers that all factors have equal weight, which is one of its deficiencies $[107,108]$. Where the weight of the factors equals to each other. Firstly, we categorized each factor into five categories. These are 1,3,5,7, and 9 for the not suitable, less suitable, moderately suitable, suitable, and most suitable for landfill location, respectively. The weight of these five categories was identified according to the possibility of air, water, and soil contamination for the surrounding areas of the proposed landfill. The relationship between LFSs and landfill PFs is shown in Table 3. Column "Rank" shows the final WSM ranks for the factors used to select the LFSs. Following is a summation of whole PFs using the equation proposed by $[109,110]$.

$$
W S M=\sum_{i=1}^{n} w_{j} a_{i j}
$$

where $n$ is the number of factors, $a_{i j}$ is the actual value of the $i$ th of the $j$ th criterion and $w_{j}$ is the weight of the $j$ th criterion.

\subsection{Weighted Product Model (WPM)}

WPM is very similar to the WSM, the essential variation is that instead of summation in the mathematical expression there is multiplication $[109,110]$. Similar to WSM, the weight of factors equals to each other. We used the same weight of the classes used in WSM (Table 3 column "Rank") to select the suitable LFSs. Equation (4) suggested by Bridgman (1922) was implemented [109].

$$
W P M=\prod_{i=1}^{n}\left(x_{k j} / x_{i j}\right)^{w_{i}}
$$


where $n$ is the number of factors, $x_{i j}$ is the actual value of the $i$ th of the $j$ th criterion (Table 3 ), $x_{k j}$ is relative value, and $w_{i}$ is the weight of the $j$ th criterion.

\subsection{Technique for Order Performance by Similarity to an Ideal Solution (TOPSIS)}

The alternative of choosing the shortest distance from the ideal best solution and the longest distance from the ideal worst solution in the TOPSIS method, makes this method suitable for LFS selection [111-113]. This method is reliable because the decision makers may desire a decision not only on the most suitable LFSs but also to avoid unsuitable sites [113]. Following steps that have been used to implement TOPSIS method [71,109-112,114-119]. As a first step, we utilized the same weight of the classes in Table 3 (column "Rank") to build the TOPSIS method. Then, we normalized each PF $X_{i j}^{\prime}$ using Equation (5).

$$
X_{i j}^{\prime}=\frac{X_{i j}}{\sqrt{\sum_{j=0}^{n} X^{2}}}
$$

where $X_{i j}$ is pixel value.

Furthermore, we compute the suitability value of the $\mathrm{PF} W_{j}$ by calculating the mean of the weights given by previous eleven papers (Table 5 ), and, hence, structured the normal weighting matrix $V_{i j}$ by multiplying the normalized PF by its weight Equation (6).

$$
V_{i j}=X_{i j}^{\prime} \times W_{j}
$$

\begin{tabular}{|c|c|c|c|c|c|c|c|c|c|c|c|c|c|c|c|}
\hline \multirow[b]{2}{*}{ 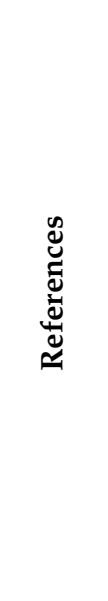 } & \multicolumn{15}{|c|}{ Factors } \\
\hline & 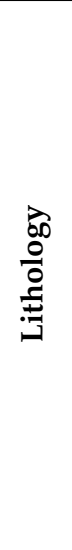 & 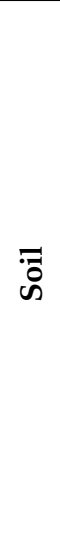 & $\stackrel{\cup}{\mathcal{U}}$ & 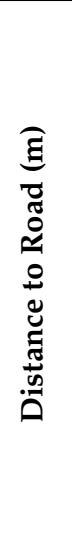 & $\begin{array}{l}\text { o } \\
\frac{0}{a} \\
\frac{0}{\omega}\end{array}$ & $\underset{\mathfrak{E}}{\widehat{\Xi}}$ & 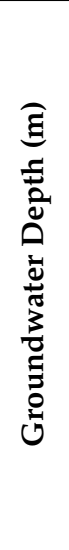 & 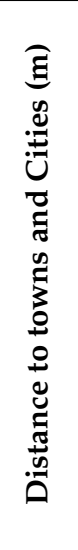 & 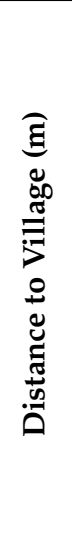 & 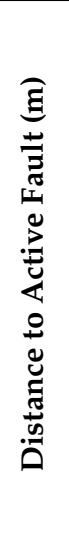 & 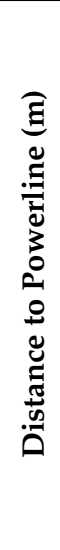 & 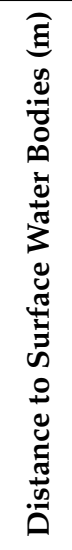 & 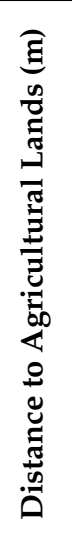 & 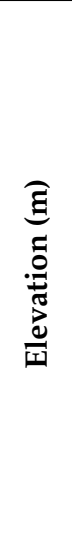 & 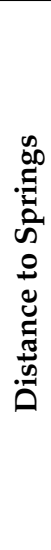 \\
\hline [66] & & 3 & & 3 & 1 & & 9 & 7 & 7 & & & 9 & 1 & & \\
\hline [85] & 7 & & 3 & 1 & 1 & & 7 & & & 5 & & 9 & & 1 & 9 \\
\hline [120] & 5 & & 3 & 3 & 3 & & & 9 & 9 & 5 & & 9 & & 1 & 9 \\
\hline [38] & 1 & & 9 & 7 & 1 & & 7 & 9 & 9 & 3 & & 7 & & 3 & \\
\hline [8] & 7 & & 5 & 3 & 4 & & 7 & 9 & 7 & & & 7 & & 4 & \\
\hline [40] & & 3 & 1 & 2 & 2 & & 9 & 7 & 5 & & & 7 & 2 & 3 & \\
\hline [39] & 1 & 3 & 5 & & 4 & & 7 & 9 & 9 & 2 & & & & 1 & \\
\hline [43] & & 3 & 1 & 2 & 2 & & 9 & 7 & 5 & & & 7 & 2 & 3 & \\
\hline [121] & & & & 3 & 3 & & & 2 & 9 & & & 9 & & & 9 \\
\hline [122] & 9 & & & 1 & 4 & & & 1 & 1 & 7 & & & & 2 & \\
\hline [5] & 9 & & 7 & 6 & 6 & & 9 & 8 & 7 & & & 9 & & & 9 \\
\hline $\mathrm{W}_{\text {Mean }}$ & 5.6 & 3 & 4.3 & 3.1 & 2.8 & & 8 & 6.8 & 6.8 & 4.4 & & 8.1 & 1.7 & 2.3 & 9 \\
\hline Weight & 7 & 3 & 4 & 3 & 3 & 1 & 8 & 7 & 7 & 5 & 3 & 9 & 2 & 2 & 9 \\
\hline
\end{tabular}

Table 5. Calculating the weight of the PF. 
The Euclidean distance from the ideal best $\left(S_{i^{+}}\right)$and Euclidean distance from the ideal worst $\left(S_{i^{-}}\right)$value for each layer were calculated by using Equations (7) and (8), respectively. The final step was accomplished by calculating the performance score $\left(P_{i}\right)$ using Equation (9).

$$
\begin{gathered}
S_{i^{+}}=\left[\sum_{j=1}^{m}\left(V_{i j}-V_{j^{+}}\right)^{2}\right]^{0.5} \\
S_{i^{-}}=\left[\sum_{j=1}^{m}\left(V_{i j}-V_{j^{-}}\right)^{2}\right]^{0.5} \\
P_{i}=\frac{S_{i^{-}}}{S_{i^{+}}+S_{i^{-}}}
\end{gathered}
$$

\subsection{Analytic Hierarchy Process (AHP)}

The AHP method proposed by [123]. It measures the index weight by comparing the PFs with each other [124]. It is one of the most common approaches applied for LFS selection. The GIS environment was used to LFSs, ratings of each PF are provided on a five-point continuous scale (Table 3 column "Rank"). While the suitability weight of the PF was computed by calculating the mean of the weights (Table 5). This was based on a simple review of 11 papers that have applied these PFs for LFS selection. Map of suitable sites for LFS is computed by the raster overlay algorithm, using Equation (10) [125]:

$$
A H P=\sum_{i=1}^{n} x_{i} w_{i}
$$

where $x_{i}$ is the value of PF $i$ [where $i=$ (list of PFs in Table 5)], $w_{i}$ is the weight for PF $i$, and $n$ is the number of PFs (Table 3 column "Rank"). We correlated all PFs used by normalizing their scales and units following the common equation, Equation (11). The final normalized weights were computed in Table 3 column "Normalized weight".

$$
Z_{i}=\frac{X_{i}-X_{\min }}{X_{\max }-X_{\min }}
$$

where $Z_{i}$ is normalized value of pixel, $X_{i}$ is the value of pixel, $X_{\min }$ is the minimum value of pixel and $X_{\max }$ is the maximum value of pixel.

The resulting maps using the WSM, WPM, TOPSIS and AHP methods were grouped into five classes, which are most suitable, suitable, moderately suitable, less suitable, and not suitable for landfill. We determined the final suitable LFSs based on the average weights of the landfill probability maps. The pixels that have average ranking $\geq$ moderate suitable were selected as suitable sites for landfill.

\section{Results}

Besides the BO map, which shows the suitable landfill locations within the TRB (Figure 8), we generated four suitability maps for LFSs using WSM, WPM, TOPSIS, and AHP methods in the ArcGIS environment. In BO maps, the suitable landfill locations are presented in red color while the unsuitable locations appear in beige. Figure 8A shows suitable landfill locations after combining all normalized binary maps using BO conditions, which are stated in Table 4, while Figure 8B exhibits the results without the distance to agricultural lands condition. Nearly all suitable sites are placed in the center and to the east of the TRB (Figure $8 \mathrm{~A}$ ). The suitable locations represent $0.13 \%$ and $4.33 \%$ for the BO with and without agricultural lands condition, respectively. 

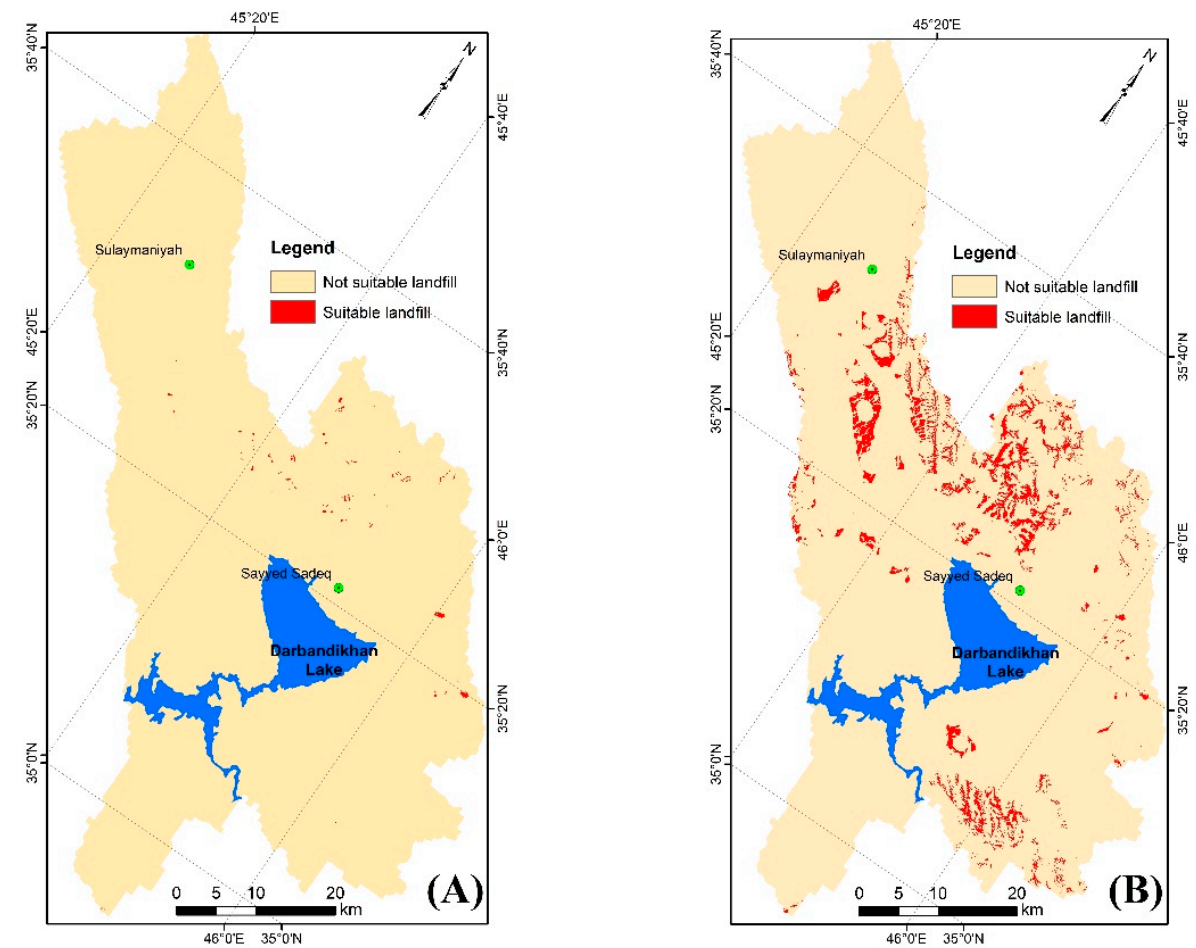

Figure 8. Boolean Overlay (BO) results (A) with all PFs (B) all PFs avoided except the distance to agricultural lands factor.

The final spatial distribution for LFSs probability maps based on the WSM, WPM, TOPSIS, and AHP models were developed using 15 PFs. The weights of the PFs have been estimated by using the prediction model Equations (3), (4) and (7)-(10). For each method, each PF has a specific predictive weight, which differs from one model to another. Wide range of the predictive weights means high effectiveness of these factors for LFS selection. We classified the LFS selection map into five groups using equal intervals. We used the frequency threshold levels (i.e., 20, 40, 60, and 80\%), representing "Not suitable", "Less suitable", "Moderate suitable", "Suitable", and "Most suitable".

The distributions for LFS suitability of WSM and AHP are very close to each other (Figure 9A,D). The WSM, TOPSIS and AHP landfill maps exhibit that their spatial distributions are somewhat similar, where more than $96.6 \%$ of "very high" and "high" probability classes are shared between these three methods. For the "very high" and "high" probability classes, the similarity between WPM and other methods is less than $11 \%$. For these three models the suitable and most suitable areas for LFSs are located close to the watershed boundary of the TRB and those for "not suitable" and "less suitable" areas are placed in the center of the TRB (Figures 9 and 10A). 

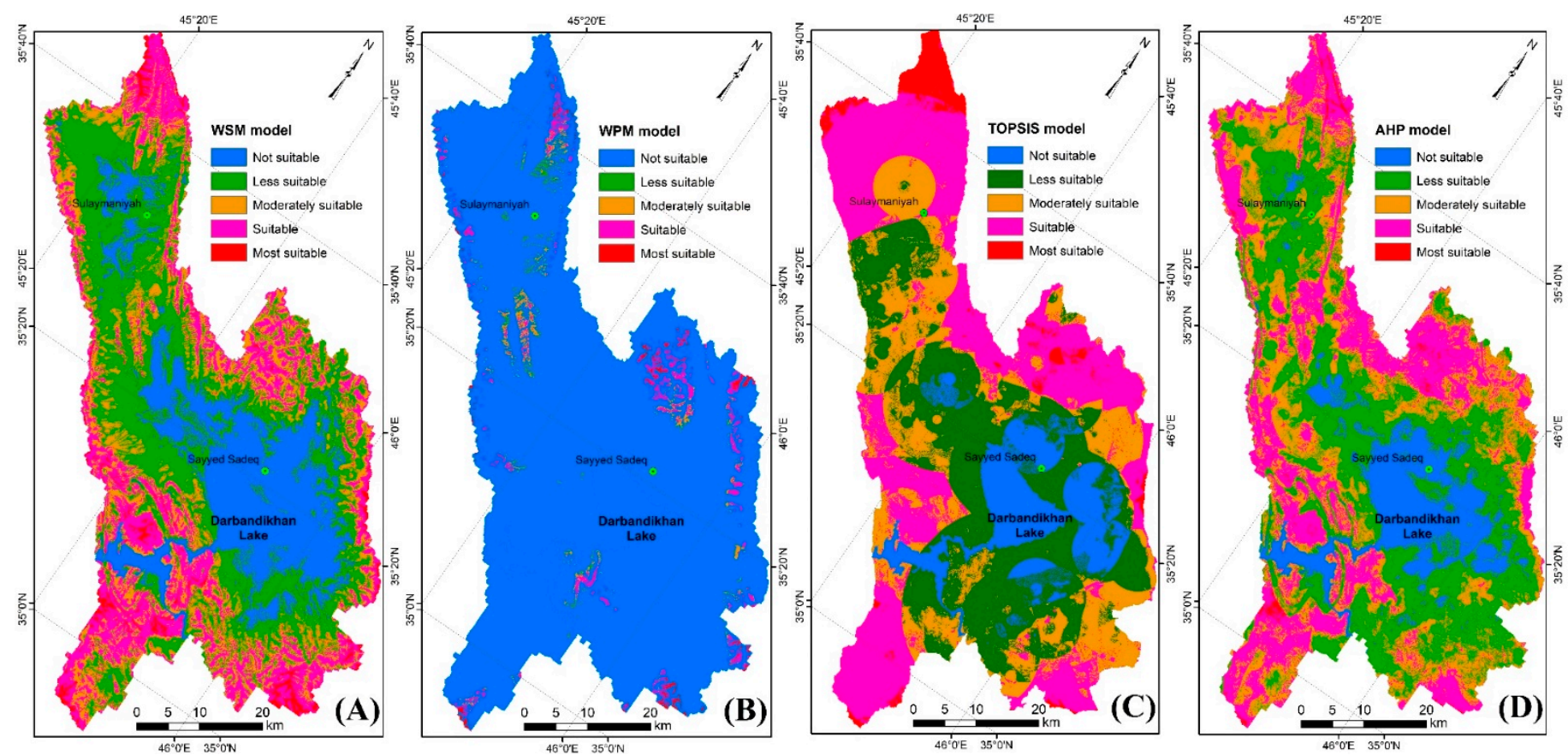

Figure 9. Spatial distribution of LFS probability of the TRB: (A) WSM; (B) WPM; (C) TOPSIS; and (D) AHP.
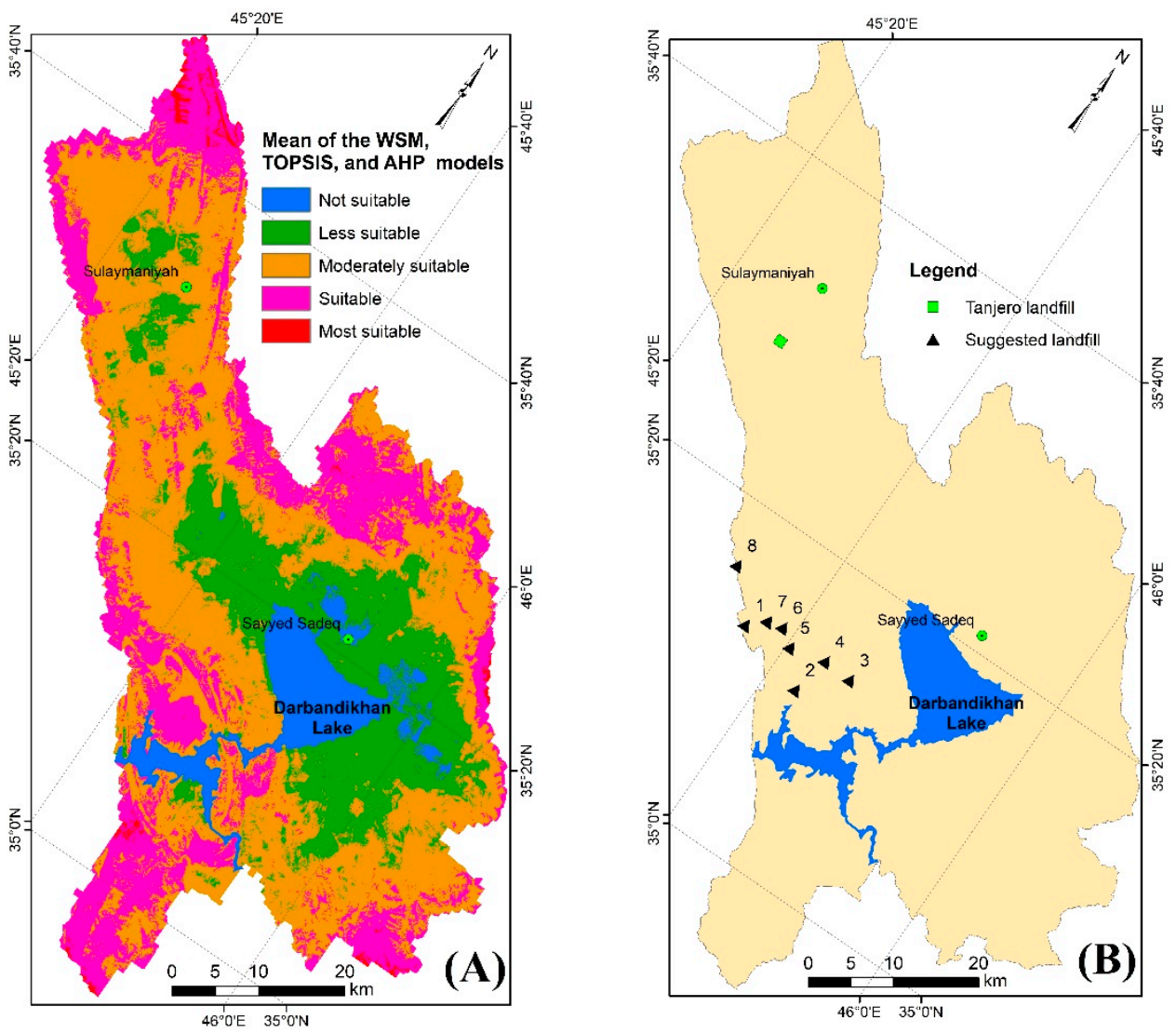

Figure 10. (A) Spatial distribution of LFS probability of the study area using average of the WSM, TOSIS, and AHP; (B) the location of the suggested LFSs, which have areas more than, $1 \mathrm{~km}^{2}$.

We calculated average map of the WSM, TOPSIS, and AHP models (Figure 10A). The WSM has been neglected from our consideration (See Section 6.2). Based on Figure 10A, eight best sites for landfill have been selected. Several areas appeared as suitable sites for 
LF, but most of them have small areas. Figure 10B and Table 6 show the locations of the eight suggested LFSs, with average landfill suitability weight $\geq 70 \%$ for the WSM, TOPSIS, and AHP models. These suitable sites are placed in the western part of the TRB, which have total area of $18.35 \mathrm{~km}^{2}$.

Table 6. Number and location coordinates of the biggest eight suggested landfill within Projected Coordinate System UTM/WGS 84 zone 38N.

\begin{tabular}{cccc}
\hline No. & Easting & Northing & Area $\left.\mathbf{( k m}^{\mathbf{2}}\right)$ \\
\hline 1 & 555381 & 3897517 & 1.63 \\
2 & 564557 & 3894646 & 2.23 \\
3 & 569143 & 3899259 & 1.69 \\
4 & 565540 & 3899390 & 2.68 \\
5 & 561218 & 3898361 & 4.65 \\
6 & 559192 & 3899796 & 1.03 \\
7 & 557291 & 3899372 & 3.04 \\
8 & 550614 & 3902710 & 1.4 \\
\hline
\end{tabular}

Figure 11 shows the relationship between the suitability of the suggested sites and the PFs. All the eight suggested sites are lying out of [19] studied area. They are located in suitable lithological units and far from springs, with lower suitability "but acceptable" distance to the villages. The most suitable landfill location is Site- 6 while the least suitable location is Site-5.

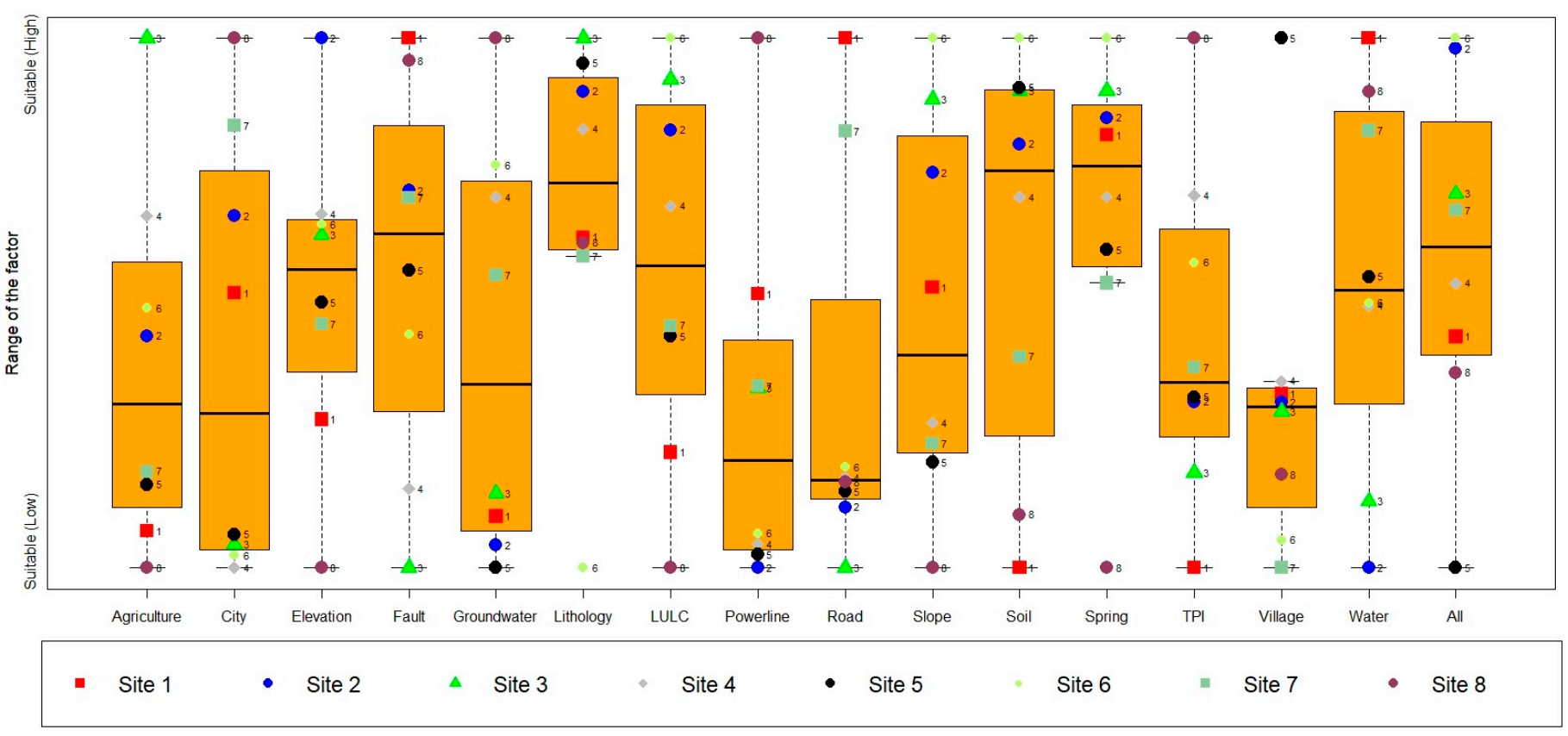

Figure 11. Relationship between suitability of the 8 LFSs suggested and suitability weight of PFs.

\section{Discussion}

\subsection{Evaluation Tanjero Landfill}

This study was prompted by our concern for the uncontrolled solid waste dump site, the Tanjero dump, which is the only MSW site in the Sulaymaniyah governorate [48]. Field investigations and previous studies (e.g., [49]), reveal that the Tanjero dump was used to dispose of huge amount of oil refineries, cement plants, and hospitals waste. No study has been done to evaluate the Tanjero dump and propose alternative locations that meet accepted MSW citing criteria. This research aimed at filling this need by proposing suitable locations based on scientific studies. 
There was a lack of adequate and reliable data that could be used as LFS selection criteria available for the study area, which limited our evaluation of the MCDA models statistically. This prompted us to follow the recent literature [2,3,20-42] (Table 1) for selecting the most important PFs (criteria) to select LFSs. In addition, we included TPI as one of the PFs, because [52,55] had found that using TPI instead of the slope aspect increased the accuracy of lithological classification for landslide susceptibility prediction. Several studies have been done to simulate and evaluate the disaster of landfills sliding, such as [126-128]. As the study area is a mountainous, it should be noted that TPI has been applied for the first time for LFS selection.

Figure 12 shows the mean weight of the 15 factors that have been evaluated for Tanjero landfill. The minimum, first quarter, third quarter, maximum, and average, of the mean weight of these PFs are $0.0001,0.0523,0.2981,1$, and 0.2045 , respectively. In other words, almost all the PFs (except the distance to surface water bodies and soil factors), used to evaluate Tanjero LFSs range between not suitable and less suitable classes.

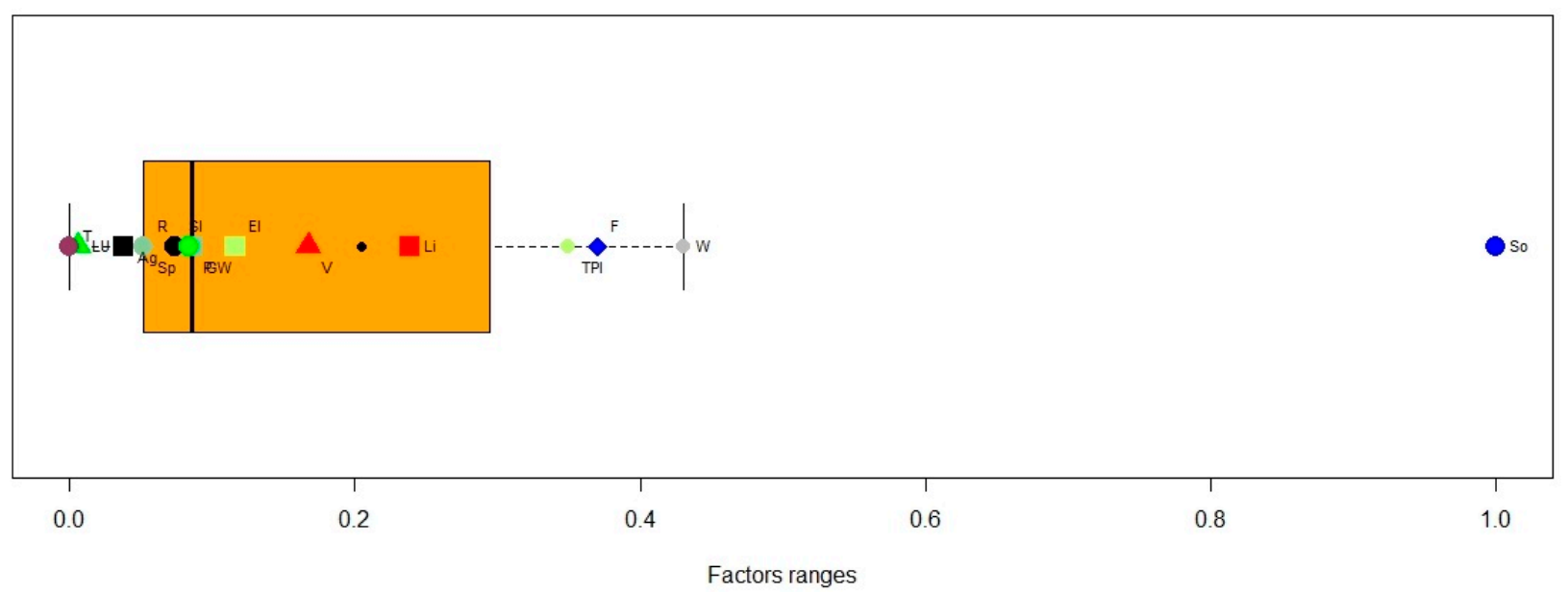

Figure 12. Boxplot shows the mean weight ranges of the 15 factors for landfills within the Tanjero basin, where Li is lithology, So is Soil, LU is land use and land cover, $\mathrm{R}$ is distance to the road, $\mathrm{Sl}$ is slope, TPI is topographic position index, GW is groundwater depth, $\mathrm{T}$ is distance to the towns and cities, $\mathrm{V}$ is distance to village, $\mathrm{F}$ is distance to the active fault, $\mathrm{P}$ is distance to the powerline, $\mathrm{W}$ is distance to surface water bodies, Ag is distance to the agricultural lands, El is elevation, and Sp is distance to the springs.

As the lithology is one of the most important factors [5,122], which is controlling directly and indirectly the suitability of LFS selection (Table 5). The lithology of the Tanjero landfill is represented by the Tanjero Formation, which consists of an alternation of shale, sandstone, claystone, mud, and conglomerate [60], which allow higher rate of water infiltration forming large quantity of leakage that will contaminate the groundwater system. This formation can be classified as less suitable for waste dump.

Although the distance from Tanjero dump to the surface water bodies is within the moderate suitability class, its ranking is lower than the accepted range (43\%). Only the soil $\mathrm{PF}$ is acceptable for selecting the Tanjero dump (Figure 12).

We considered that the range of suitability is from 0 to 1 . The average suitability of the existing Tanjero LFS using WPM, WSM, AHP, and TOPSIS method are $0.01,0.28,0.41$, and 0.48 , respectively, giving it the subtility ranking of 0.39 . Therefore, it is not adequate for the existing Tanjero dump to be considered a suitable dump site for MSW in the Sulaymaniyah governorate.

\subsection{Statistical Evaluation of the MCDA Used in TRB}

Although the BO determines suitable regions for landfill, it has a significant disadvantage by not providing suitable alternatives if the conditions mismatch [98]. Therefore, we used the MCDA for selecting the suitable LFSs. For the purpose of evaluating our 
statistical models, we tested the relationship between all proposed models in this study. Figures 13 and 14 show the uncertainty tests of the four MCDA models. Figure 13 shows six tested graphs of the relationships between the WSM, WPM, AHP, and TOPSIS. In this figure, all $(3,615,924)$ pixels within the TRB have been tested. It shows that the best correlations are between AHP and TOPSIS and AHP and WSM models, with $\mathrm{R}^{2}$ of 0.62 and 0.6, respectively. However, the correlation $\left(\mathrm{R}^{2}\right)$ between the TOPSIS and WSM is 0.36 . Other correlations (i.e., WPM with WSM, AHP, and TOPSIS) are very weak. The worst correlation is between WPM and TOPSIS methods. Therefore, as shown in Figure 10A, we ignored WPM model from our consideration in this study.
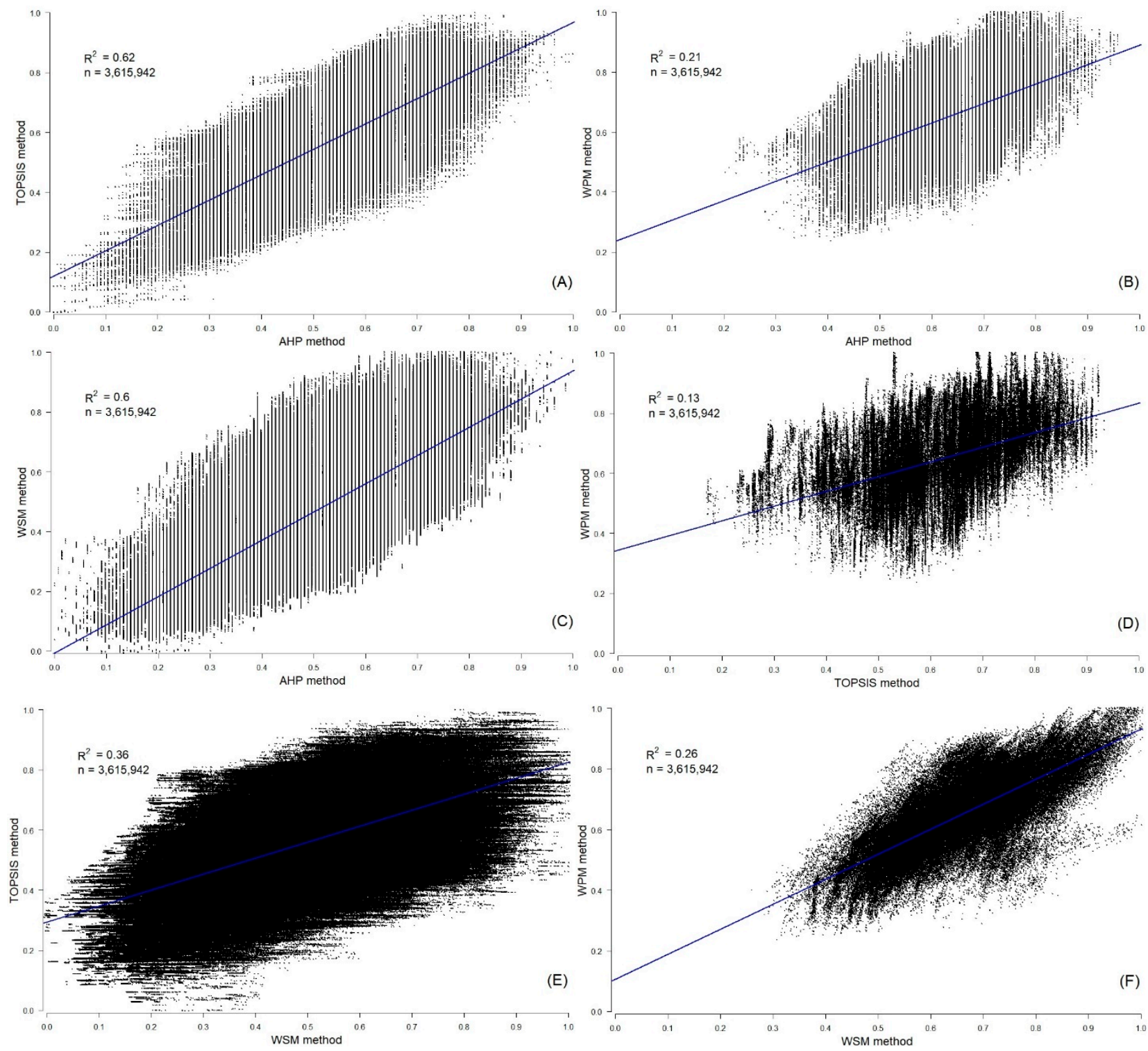

Figure 13. Similarity analysis using the correlation between the statistical models, where the correlations are between (A) AHP and TOPSIS, (B) AHP and WPM, (C) AHP and WSM, (D) TOPSIS and WPM, (E) WSM and TOPSIS, and (F) WSM and WPM models. 


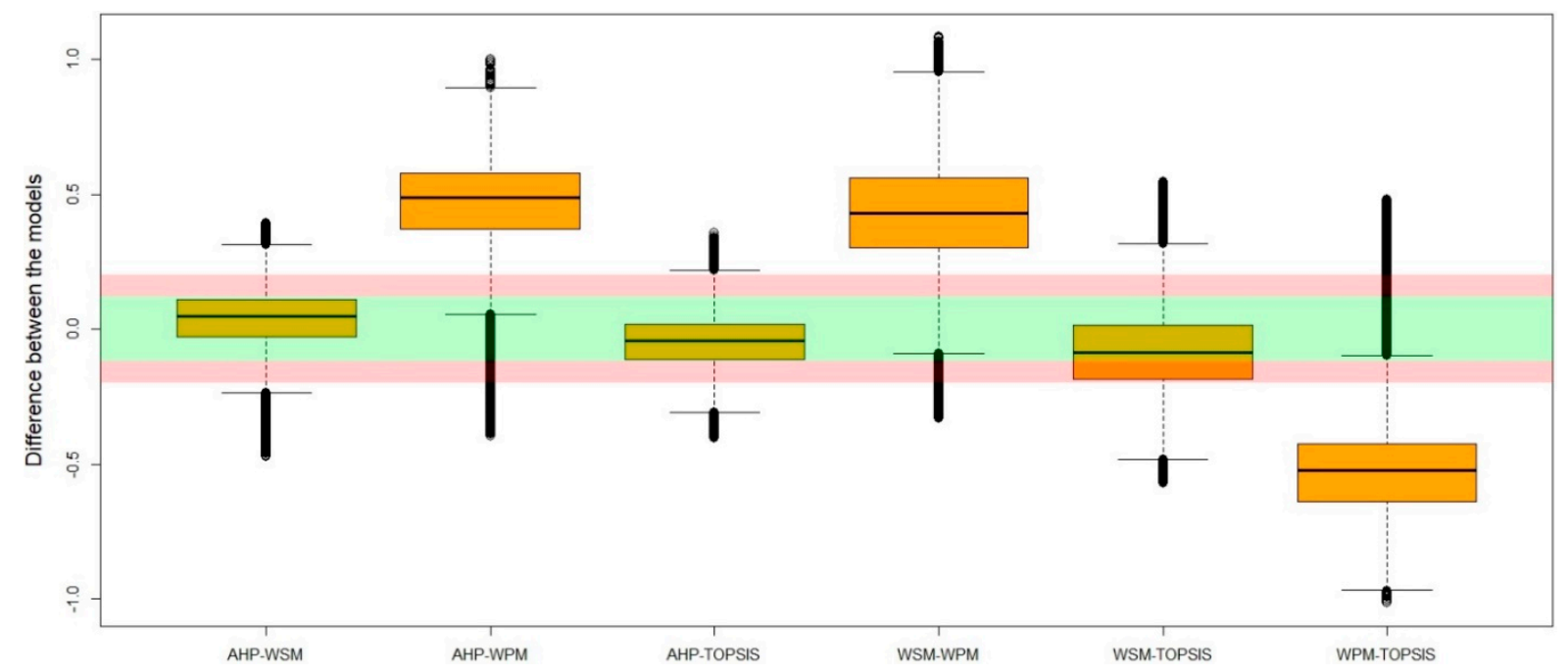

Figure 14. Sensitivity analysis of statistical models.

Figure 14 shows the subtraction between AHP and TOPSIS, AHP and WPM, AHP and WSM, TOPSIS and WPM, WSM and TOPSIS, and WSM and WPM. The best matching between each two subtracted models will be close to the zero value. The higher value of any subtracted model means higher difference between these models, which in turns means less matching. Subtraction between AHP-TOPSIS and AHP-WSM show the best matching (located within green zone between \pm 0.12 ) among other subtracted models, similar to TOPSIS and WSM (located within red zone between \pm 0.2 ). The highest difference can be noted between AHP-WPM, TOPSIS-WPM, WSM-WPM. This pattern supports our decision to ignore the WPM from our interpretation.

\subsection{Landfill Sites Suitability}

It should be noted that the above rankings are generalized for quick and broad evaluation of candidate sites for LFS. The final selection of LFS should be made after detailed on-site surface and subsurface investigations.

Improving the sites to be suitable for landfilling can be achieved by modifying the suitability factors that render an otherwise suitable sites score low in the analyses. As can be noticed in Figure 11, some factors lie within the lower part of the suitability boxplot. For example, distance from villages is the least suitable factor among the eight selected LFSs within the TRB, with Site-7 being the least suitable (Figure 11). As there are a number of very small villages distributed within the TRB, consisting of a few houses only (less than ten), so the lower suitability ranking of these villages can be neglected relative to the main towns and cities.

The second and the third lower suitable factors are the distances to powerline and distance to the road. Small villages in the TRB have their own powerlines and paved roads, which will affect the suitability ranking of the later factors. The fourth lower suitable factor is the distance to the agricultural land. It causes misinterpretation in the ranking as well because it takes into account wild shrubs and forest trees, which do not belong to cropped plants. To overcome this constraint, we proposed the overall ranking to include all PFs (Figure 11), which show higher suitability except for Site-6, while the most suitable LFS is Site-5.

\subsection{Models Validation}

In addition to the fieldtrip to check the suitability of the eight selected LFSs, we obtained the data of twelve groundwater samples stated by [81] (Figure 15A). These data were collected from boreholes dug in Tanjero and Quaternary aquifers outcropped within TRB $[60,61,81]$. Several studies have used the total dissolved solids (TDS) in water to validate the groundwater contamination $[129,130]$. The TDS has a direct relationship with 
groundwater contamination as a result of leakage from the recharge area. The higher TDS, the higher groundwater contamination $[129,130]$, and thus the lower suitability of landfilling. In other words, the decreasing of the TDS concentration is consistent with the increase of the LFS selection suitability.
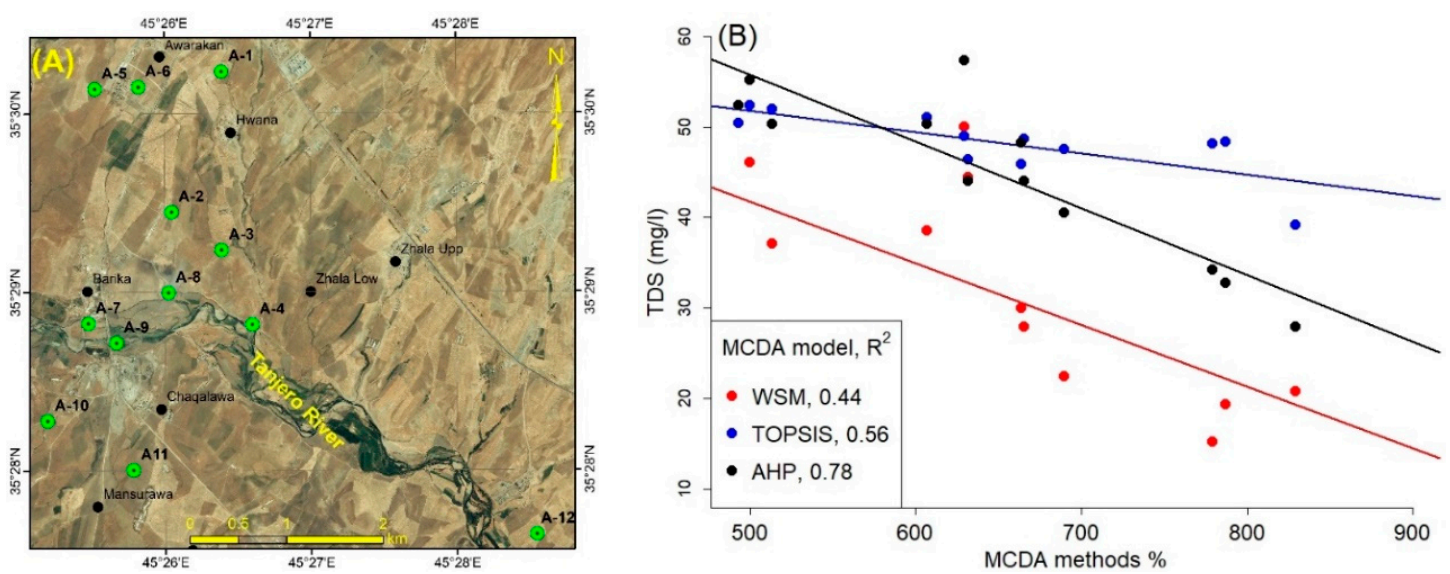

Figure 15. (A) QuickBird satellite images overlapped by 12 groundwater samples collected from boreholes dug in Tanjero and Quaternary aquifers [81]; (B) the relation between the values of the MCDA methods (i.e., WSM, TOSIS, and AHP) and the TDS of the 12 groundwater samples.

TDS concentrations of the twelve groundwater samples were used to validate our results. Figure 15B shows the relation between the TDS and the WSM, TOPSIS, and AHP models. The TDS shows an inverse relationship with the WSM, TOPSIS, and AHP models where the $R^{2}$ values are $0.44,0.56$, and 0.78 , respectively. The WPM model has been excluded as the $\mathrm{R}^{2}$ value is $<0.1$. While the AHP model shows the best results based on the strong relationship with the TDS concentration.

\section{Conclusions}

The main aim of this paper was to recognize suitable landfill sites (LFSs) in the Tanjero River Basin (TRB) in the Kurdistan region, Iraq. In the current study, Boolean Overlay (BO) in addition to four Multi-Criteria Decision-Analysis (MCDA) models included Weighted Sum Method (WSM), Weighted Product Method (WPM), Analytic Hierarchy Process (AHP), and Technique for Order Performance by Similarity to an Ideal Solution (TOPSIS) were applied to enable combined the use of the 15 thematic layers. The distribution maps for LFSs probability from WSM and AHP are very close to each other; while the WSM, TOPSIS and AHP landfill results exhibit that their spatial distributions are somewhat similar; while the similarity between WPM and other methods is less than $11 \%$. The accuracy of all methods was calculated, and the best accuracy was achieved by AHP method.

According to the results, the final suitable LFSs were identified by calculating average weights of the WSM, TOPSIS and AHP maps. Accordingly, the pixels weights that have suitable and very suitable ranks have been nominated for landfill.

To sum up, based on the final analyses, most of the suitable sites are located close to the TRB boundary. Eight suitable sites have been identified, that have the best condition for citing MSW landfills. These sites are situated in the western part of the TRB, and the most suitable site is Site- 6 and the less suitable is Site- 5 . According to this research, the current location of the Sulaymaniyah dump is not suitable and its location might lead to pollution in the area. It is worth noting that ours is the first study to have used the Topographic Position Index (TPI) to select MSW LFSs. From 12 borehole dug in the TRB, a validation shows that the best model is AHP, where it has an inverse strong relationship $\left(R^{2}=0.78\right)$ with the TDS model. Finally, we recommend that the most suitable site among the eight determined sites for choosing landfill should be based on detailed on-site surface and subsurface investigations. 
Author Contributions: Conceptualization, A.A.O.; methodology, A.A.O.; software, A.A.O.; validation, A.A.O., A.K.O., and D.A.M.A.-M.; formal analysis, A.A.O.; investigation, A.A.O., A.F.A.-M., A.T.S., and Y.I.A.-S.; resources, A.A.O., D.A.M.A.-M., S.G.S.; V.L., and Z.T.A.-A; writing-original draft preparation A.A.O., A.K.O., and M.P.; writing—review and editing, A.A.O., and A.K.O.; All authors have read and agreed to the published version of the manuscript.

Funding: This research received no external funding.

Institutional Review Board Statement: Not applicable.

Informed Consent Statement: Not applicable.

Data Availability Statement: We do not report any data.

Acknowledgments: We would like to thank the USGS, OCHA-IRAQ, Sulaymaniyah groundwater Directorate, and ESA for their free data used in this study. Also, we would like to thank ESA and SEOM (Scientific Exploitation of Operational Missions) for providing SNAP software. The First author would like to thank GREEN CHARTER GC. Foundation and elbarlament organization from Germany for the fruitful discussion during the water dialogue-Clean Tigris project and provided the roadmap for water challenges and solutions in context of Iraq. The second author would like to thank CARA for their support to his research. Our appreciation fo Syed E. Hasan from Department of Earth \& Environmental Sciences, University of Missouri, Kansas City, US for editing the language of the manuscript.

Conflicts of Interest: The authors declare no conflict of interest.

\section{References}

1. Akintorinwa, O.J.; Okoro, O.V. Combine electrical resistivity method and multi-criteria GIS-based modeling for landfill site selection in the Southwestern Nigeria. Environ. Earth Sci. 2019, 78, 162. [CrossRef]

2. Eskandari, M.; Homaee, M.; Falamaki, A. Landfill site selection for municipal solid wastes in mountainous areas with landslide susceptibility. Environ. Sci. Pollut. Res. 2016, 23, 12423-12434. [CrossRef]

3. Khoshand, A.; Bafrani, A.H.; Zahedipour, M.; Mirbagheri, S.A.; Ehtehsami, M. Prevention of landfill pollution by multicriteria spatial decision support systems (MC-SDSS): Development, implementation, and case study. Environ. Sci. Pollut. Res. 2018, 25, 8415-8431. [CrossRef]

4. Motlagh, Z.K.; Sayadi, M.H. Siting MSW landfills using MCE methodology in GIS environment (Case study: Birjand plain, Iran). Waste Manag. 2015, 46, 322-337. [CrossRef]

5. Karimi, H.; Amiri, S.; Huang, J.; Karimi, A. Integrating GIS and multi-criteria decision analysis for landfill site selection, case study: Javanrood County in Iran. Int. J. Environ. Sci. Technol. 2018, 16, 7305-7318. [CrossRef]

6. World Bank. Urban Development Overview: Development News, Research, Data; FCT Book: Washington, DC, USA, 2021.

7. Zhang, R.; Yang, S.; An, Y.; Wang, Y.; Lei, Y.; Song, L. Antibiotics and antibiotic resistance genes in landfills: A review. Sci. Total Environ. 2021, 806, 150647. [CrossRef]

8. Hamzeh, M.; Ali Abbaspour, R.; Davalou, R. Raster-based outranking method: A new approach for municipal solid waste landfill (MSW) siting. Environ. Sci. Pollut. Res. 2015, 22, 12511-12524. [CrossRef]

9. Saaty, T.L.; Vargas, L.G. Hierarchical analysis of behavior in competition: Prediction in chess. Behav. Sci. 1980, $25,180-191$. [CrossRef]

10. Hwang, C.; Yoon, K. Multiple Attribute Decision Making; Springer: Berlin, Germany, 1981.

11. Fishburn, P.C. Additive Utilities with Incomplete Product Set: Applications to Priorities and Assignments. Oper. Res. 1967, 15. [CrossRef]

12. Miller, D.W.; Starr, M.K. Executive Decisions and Operations Research; Prentice-Hall international Series in Management; PrenticeHall: Hoboken, NJ, USA, 1969.

13. Damasceno Pavani, I.; Ennes Cicerelli, R.; de Almeida, T.; Zandonadi Moura, L.; Contreras, F. Allocation of sanitary landfill in consortium: Strategy for the Brazilian municipalities in the State of Amazonas. Environ. Monit. Assess. 2019, 191, 39. [CrossRef]

14. Ekmekçioĝlu, M.; Kaya, T.; Kahraman, C. Fuzzy multicriteria disposal method and site selection for municipal solid waste. Waste Manag. 2010, 30, 1729-1736. [CrossRef]

15. Coban, A.; Ertis, I.F.; Cavdaroglu, N.A. Municipal solid waste management via multi-criteria decision making methods: A case study in Istanbul, Turkey. J. Clean. Prod. 2018, 180, 159-167. [CrossRef]

16. Bah, Y.; Tsiko, R.G. Landfill site selection by integrating geographical information systems and multi-criteria decision analysis: A case study of Freetown, Sierra Leone. Afr. Geogr. Rev. 2011, 30, 67-99. [CrossRef]

17. Shahabi, H.; Keihanfard, S.; Ahmad, B.B.; Amiri, M.J.T. Evaluating Boolean, AHP and WLC methods for the selection of waste landfill sites using GIS and satellite images. Environ. Earth Sci. 2014, 71, 4221-4233. [CrossRef]

18. Cheng, S.; Chan, C.W.; Huang, G.H. Using multiple criteria decision analysis for supporting decisions of solid waste management. J. Environ. Sci. Health Part A Toxic/Hazard. Subst. Environ. Eng. 2002, 37, 975-990. [CrossRef] 
19. Alkaradaghi, K.; Ali, S.S.; Al-Ansari, N.; Laue, J.; Chabuk, A. Landfill site selection using MCDM methods and GIS in the Sulaimaniyah Governorate, Iraq. Sustainability 2019, 11, 4530. [CrossRef]

20. Saatsaz, M.; Monsef, I.; Rahmani, M.; Ghods, A. Site suitability evaluation of an old operating landfill using AHP and GIS techniques and integrated hydrogeological and geophysical surveys. Environ. Monit. Assess. 2018, 190, 144. [CrossRef]

21. Jamshidi, A.; Jahandizi, E.K.; Moshtaghie, M.; Monavari, S.M.; Tajziehchi, S.; Hashemi, A.; Jamshidi, M.; Allahgholi, L. Landfill site selection: A basis toward achieving sustainable waste management. Pol. J. Environ. Stud. 2014, 24, 1021-1029. [CrossRef]

22. Bahrani, S.; Ebadi, T.; Ehsani, H.; Yousefi, H.; Maknoon, R. Modeling landfill site selection by multi-criteria decision making and fuzzy functions in GIS, case study: Shabestar, Iran. Environ. Earth Sci. 2016, 75, 337. [CrossRef]

23. Bosompem, C.; Stemn, E.; Fei-Baffoe, B. Multi-criteria GIS-based siting of transfer station for municipal solid waste: The case of Kumasi Metropolitan Area, Ghana. Waste Manag. Res. 2016, 34, 1054-1063. [CrossRef]

24. Chabuk, A.; Al-Ansari, N.; Hussain, H.M.; Knutsson, S.; Pusch, R. Landfill site selection using geographic information system and analytical hierarchy process: A case study Al-Hillah Qadhaa, Babylon, Iraq. Waste Manag. Res. 2016, 34, 427-437. [CrossRef] [PubMed]

25. Djokanović, S.; Abolmasov, B.; Jevremović, D. GIS application for landfill site selection: A case study in Pančevo, Serbia. Bull. Eng. Geol. Environ. 2016, 75, 1273-1299. [CrossRef]

26. El Maguiri, A.; Kissi, B.; Idrissi, L.; Souabi, S. Landfill site selection using GIS, remote sensing and multicriteria decision analysis: Case of the city of Mohammedia, Morocco. Bull. Eng. Geol. Environ. 2016, 75, 1301-1309. [CrossRef]

27. Torabi-Kaveh, M.; Babazadeh, R.; Mohammadi, S.D.; Zaresefat, M. Landfill site selection using combination of GIS and fuzzy AHP, a case study: Iranshahr, Iran. Waste Manag. Res. 2016, 34, 438-448. [CrossRef]

28. Sureshkumar, M.; Sivakumar, R.; Nagarajan, M. Selection of alternative landfill site in Kanchipuram, India by using gis and multicriteria decision analysis. Appl. Ecol. Environ. Res. 2017, 15, 627-636. [CrossRef]

29. Güler, D.; Yomralığlu, T. Alternative suitable landfill site selection using analytic hierarchy process and geographic information systems: A case study in Istanbul. Environ. Earth Sci. 2017, 76, 678. [CrossRef]

30. Rahmat, Z.G.; Niri, M.V.; Alavi, N.; Goudarzi, G.; Babaei, A.A.; Baboli, Z.; Hosseinzadeh, M. Landfill site selection using GIS and AHP: A case study: Behbahan, Iran. KSCE J. Civ. Eng. 2017, 21, 111-118. [CrossRef]

31. Jamshidi-Zanjani, A.; Rezaei, M. Landfill site selection using combination of fuzzy logic and multi-attribute decision-making approach. Environ. Earth Sci. 2017, 76, 448. [CrossRef]

32. Khademalhoseiny, M.S.; Ahmadi Nadoushan, M.; Radnezhad, H. Site selection for landfill gas extraction plant by fuzzy analytic hierarchy process and fuzzy analytic network process in the city of Najafabad, Iran. Energy Environ. 2017, 28, 763-774. [CrossRef]

33. Kursah, M.B. Resolving the landfill siting impasse: Modelling technocratic and indigenous perspectives using GIS multicriteria approach. GeoJournal 2018, 83, 707-724. [CrossRef]

34. Yildirim, V.; Memisoglu, T.; Bediroglu, S.; Colak, H.E. Municipal solid waste landfill site selection using multi-criteria decision making and gis: Case study of Bursa province. J. Environ. Eng. Landsc. Manag. 2018, 26, 107-119. [CrossRef]

35. Al-Ruzouq, R.; Shanableh, A.; Omar, M.; Al-Khayyat, G. Macro and micro geo-spatial environment consideration for landfill site selection in Sharjah, United Arab Emirates. Environ. Monit. Assess. 2018, 190, 147. [CrossRef]

36. Al-Anbari, M.A.; Thameer, M.Y.; Al-Ansari, N. Landfill site selection by weighted overlay technique: Case study of Al-Kufa, Iraq. Sustainability 2018, 10, 999. [CrossRef]

37. Soroudi, M.; Omrani, G.; Moataar, F.; Jozi, S.A. Modelling an integrated fuzzy logic and multi-criteria approach for land capability assessment for optimized municipal solid waste landfill siting yeast. Pol. J. Environ. Stud. 2018, 27, 313-323. [CrossRef]

38. Barakat, A.; Hilali, A.; Baghdadi, M.E.; Touhami, F. Landfill site selection with GIS-based multi-criteria evaluation technique. A case study in Béni Mellal-Khouribga Region, Morocco. Environ. Earth Sci. 2017, 76, 413. [CrossRef]

39. Kapilan, S.; Elangovan, K. Potential landfill site selection for solid waste disposal using GIS and multi-criteria decision analysis (MCDA). J. Cent. South Univ. 2018, 25, 570-585. [CrossRef]

40. Khodaparast, M.; Rajabi, A.M.; Edalat, A. Municipal solid waste landfill siting by using GIS and analytical hierarchy process (AHP): A case study in Qom city, Iran. Environ. Earth Sci. 2018, 77, 52. [CrossRef]

41. Vosoogh, A.; Baghvand, A.; Karbassi, A.; Nasrabadi, T. Landfill site selection using pollution potential zoning of aquifers by modified DRASTIC Method: Case study in Northeast Iran. Iran. J. Sci. Technol. Trans. Civ. Eng. 2017, 41, 229-239. [CrossRef]

42. Yousefi, H.; Javadzadeh, Z.; Noorollahi, Y.; Yousefi-Sahzabi, A. Landfill site selection using a multi-criteria decision-making method: A case study of the salafcheghan special economic zone, Iran. Sustainability 2018, 10, 1107. [CrossRef]

43. Chabuk, A.J.; Al-Ansari, N.; Hussain, H.M.; Knutsson, S.; Pusch, R. GIS-based assessment of combined AHP and SAW methods for selecting suitable sites for landfill in Al-Musayiab Qadhaa, Babylon, Iraq. Environ. Earth Sci. 2017, 76, 209. [CrossRef]

44. Directorate_of_Darbandikhan_Dam. Water-Level of Darbandikhan Reservoir; General Authority for Dams and Reservoirs: Sulaymaniyah, Iraq, 2018.

45. CityPopulation Iraq: Governorates, Major Cities \& Urban Centers-Population Statistics, Maps, Charts, Weather and Web Information. Available online: http:/ / www.citypopulation.de/Iraq-Cities.html (accessed on 20 March 2021).

46. Knowles, J.A. National solid waste management plan for Iraq. Waste Manag. Res. 2009, 27, 322-327. [CrossRef]

47. The World Bank. The Kurdistan Region of Iraq Assessing the Economic and Social Impact of the Syrian Conflict and ISIS; United Nations: Washington, DC, USA, 2015. 
48. Economides, D.; Expert, W.M.; Sector, W. Local Area Development Programme in Iraq Report on Improvement Recommendations for the Waste Management Sector; UNDP: Erbil, Iraq, 2017.

49. ICSSI Tanjero: The Struggle to Clean Up a Neglected River. Available online: https://www.iraqicivilsociety.org/archives/8184 (accessed on 25 November 2017).

50. ESA SNAP. 2018. Available online: https://step.esa.int/main/ (accessed on 20 March 2021).

51. ESRI ArcGIS. 2011. Available online: https://desktop.arcgis.com/en/ (accessed on 20 March 2021).

52. Othman, A.A.; Gloaguen, R.; Andreani, L.; Rahnama, M. Improving landslide susceptibility mapping using morphometric features in the Mawat area, Kurdistan Region, NE Iraq: Comparison of different statistical models. Geomorphology 2018, 319, 147-160. [CrossRef]

53. Foad, S. Tectonic Iraq Geological Survey Map of Iraq, Scale 1:1,000,000; Iraq Geological Survey: Baghdad, Iraq, 2012.

54. Hamasur, G.A.; Mohammad, F.O.; Ahmed, A.J. Assessment of rock slope stability along sulaimaniyah -qaradagh main road, near Dararash Village, Sulaimaniyah, NE-Iraq. Iraqi J. Sci. 2020, 61, 3266-3286. [CrossRef]

55. Othman, A.A.; Gloaguen, R. Integration of spectral, spatial and morphometric data into lithological mapping: A comparison of different Machine Learning Algorithms in the Kurdistan Region, NE Iraq. J. Asian Earth Sci. 2017, 146, 90-102. [CrossRef]

56. Othman, A.A.; Gloaguen, R. Improving lithological mapping by SVM classification of spectral and morphological features: The discovery of a new chromite body in the Mawat ophiolite complex (Kurdistan, NE Iraq). Remote Sens. 2014, 6, 6867-6896. [CrossRef]

57. Othman, A.A.; Al-Maamar, A.F.; Al-Manmi, D.A.M.; Liesenberg, V.; Hasan, S.E.; Al-Saady, Y.I.; Khwedim, K. Application of DInSAR-PSI Technology for Deformation Monitoring of the Mosul Dam, Iraq. Remote Sens. 2019, 11, 2632. [CrossRef]

58. Othman, A.A.; Gloaguen, R. Automatic extraction and size distribution of landslides in kurdistan region, NE Iraq. Remote Sens. 2013, 5, 2389-2410. [CrossRef]

59. Obaid, A.K.; Allen, M.B. Landscape expressions of tectonics in the Zagros fold-and-thrust belt. Tectonophysics 2019, 766, 20-30. [CrossRef]

60. Ma'ala, K.A. The Geology of Sulaimaniya Quadrangle Sheet No. NI-38-3, Scale 1:250000; GEOSURV: Baghdad, Iraq, 2008.

61. Barwary, A.M.; Salih, F. The Geology of Khanaqin Quadrangle, Sheet ni-38-37 (GM15), Scale 1:250000; Iraq Geological Survey: Baghdad, Iraq, 1992.

62. Koc-San, D.; San, B.T.; Bakis, V.; Helvaci, M.; Eker, Z. Multi-Criteria Decision Analysis integrated with GIS and remote sensing for astronomical observatory site selection in Antalya province, Turkey. Adv. Sp. Res. 2013, 52, 39-51. [CrossRef]

63. Ghobadi, M.H.; Babazadeh, R.; Bagheri, V. Siting MSW landfills by combining AHP with GIS in Hamedan province, western Iran Environ. Earth Sci. 2013, 70, 1823-1840. [CrossRef]

64. Abd-El Monsef, H. Optimization of municipal landfill siting in the Red Sea coastal desert using geographic information system, remote sensing and an analytical hierarchy process. Environ. Earth Sci. 2015, 74, 2283-2296. [CrossRef]

65. Nachtergaele, F.; van Velthuizen, H.; van Engelen, V.; Fischer, G.; Jones, A.; Montanarella, L.; Petri, M.; Prieler, S.; Teixeira, E.; Shi, X. Harmonized World Soil Database, version 1.2; FAO: Rome, Italy; IIASA: Laxenburg; Austria, 2012; pp. 1-50.

66. Kara, C.; Doratli, N. Application of GIS/AHP in siting sanitary landfill: A case study in Northern Cyprus. Waste Manag. Res. 2012, 30, 966-980. [CrossRef]

67. Kumar, A.; Pinto, M.C.; Candeias, C.; Dinis, P.A. Baseline maps of potentially toxic elements in the soils of Garhwal Himalayas, India: Assessment of their eco-environmental and human health risks. Land Degrad. Dev. 2021, 32, 3856-3869. [CrossRef]

68. Kumar, A.; Kumar, M.; Pandey, R.; ZhiGuo, Y.; Cabral-Pinto, M. Forest soil nutrient stocks along altitudinal range of Uttarakhand Himalayas: An aid to Nature Based Climate Solutions. CATENA 2021, 207, 105667. [CrossRef]

69. USDA. Soil Mechanics Level 1, Module 3. USDA Textural Classification Study Guide; United States Department of Agriculture: Washington, DC, USA, 1987.

70. Demesouka, O.E.; Vavatsikos, A.P.; Anagnostopoulos, K.P. GIS-based multicriteria municipal solid waste landfill suitability analysis: A review of the methodologies performed and criteria implemented. Waste Manag. Res. 2014, 32, 270-296. [CrossRef]

71. Demesouka, O.E.; Vavatsikos, A.P.; Anagnostopoulos, K.P. Suitability analysis for siting MSW landfills and its multicriteria spatial decision support system: Method, implementation and case study. Waste Manag. 2013, 33, 1190-1206. [CrossRef] [PubMed]

72. Charnpratheep, K.; Zhou, Q.; Garner, B. Preliminary landfill site screening using fuzzy geographical information systems. Waste Manag. Res. 1997, 15, 197-215. [CrossRef]

73. Ersoy, H.; Bulut, F. Spatial and multi-criteria decision analysis-based methodology for landfill site selection in growing urban regions. Waste Manag. Res. 2009, 27, 489-500. [CrossRef]

74. Weiss, A.D. Topographic position and landforms analysis. In Proceedings of the ESRI Users Conference, San Diego, CA, USA, 9-13 July 2001.

75. ESRI. ArcGIS Help Library; ESRI: West Redlands, CA, USA, 2012.

76. Abd-El Monsef, H.; Smith, S.E. Integrating remote sensing, geographic information system, and analytical hierarchy process for hazardous waste landfill site selection. Arab. J. Geosci. 2019, 12, 155. [CrossRef]

77. Sulaymaniyah Groundwater Directorate (SGD). Borehole Data and Water Level Information; SGD: Sulaymaniyah, Iraq, 2018.

78. Mustafa, O.M. Impact of Sewage Waste Water on the Environment of Tanjero River and its Basin within Sulaimani City/NE-Iraq; University of Baghdad: Baghdad, Iraq, 2006.

79. Al-hasnawi, S.S. Water Quality Index Of Tanjero River Basin Near Sulaymania City. Al-Mustansiriyah J. Sci. Res. 2012, 23, 193-200. 
80. Aziz, N.A. Pollution of Tanjero River by Some Heavy Metals Generated from Sewage Wastwater and Industrial Wastewater in Sulaimani District. J. Kirkuk Univ.-Sci. Stud. 2012, 7, 67-84. [CrossRef]

81. Kareem, A.; Mustafa, O.; Merkel, B. Geochemical and environmental investigation of the water resources of the Tanjero area, Kurdistan region, Iraq. Arab. J. Geosci. 2018, 11, 461. [CrossRef]

82. Khwakaram, A.I. On water quality of qalyasan stream, tanjero river and impact of fat, oil and grease on darbandikhan reservoir in Sulaimani City-Kurdistan Region of Iraq-Iraq. Int. J. Environ. Ecol. Fam. Urban Stud. 2016, 6, 1-12.

83. Hamamin, D.F.; Qadir, R.A.; Ali, S.S. Groundwater vulnerability map of Sulaymaniyah sub-basin using SINTACS model, Sulaymaniyah Governorate, Kurdistan Region, Iraq. J. Zankoy Sulaimani Part-A Pure Appl. Sci. 2016, 277-292. [CrossRef]

84. Othman, N.; Kane, T.; Hawrami, K.M.; Alkaradaghi, K.; Salih, F.A.; Khwa, K.; Hamafaraj, R.; Ali, T. Assessing health risks to local population from contamination sources in and around Sulaimani province; a qualitative study. J. Zankoy Sulaimani Part-A Pure Appl. Sci. 2018, 20, 45-62. [CrossRef]

85. Şener, S..; Sener, E.; Karagüzel, R. Solid waste disposal site selection with GIS and AHP methodology: A case study in SenirkentUluborlu (Isparta) Basin, Turkey. Environ. Monit. Assess. 2011, 173, 533-554. [CrossRef]

86. Rasul, A.K. Hydrochemistry and quality assessment of Derbendikhan Reservoir, Kurdistan Region, Northeastern Iraq. Arab. J. Geosci. 2019, 12, 312. [CrossRef]

87. SSWD. Sulaymaniyah Surface Water Directorate; Spring Data; SSWD: Sulaymaniyah, Iraq, 2018.

88. Isalou, A.A.; Zamani, V.; Shahmoradi, B.; Alizadeh, H. Landfill site selection using integrated fuzzy logic and analytic network process (F-ANP). Environ. Earth Sci. 2013, 68, 1745-1755. [CrossRef]

89. Kontos, T.D.; Komilis, D.P.; Halvadakis, C.P. Siting MSW landfills on Lesvos island with a GIS-based methodology. Waste Manag. Res. 2003, 21, 262-277. [CrossRef]

90. Kao, J.-J.; Lin, H.-Y. Multifactor spatial analysis for landfill siting. J. Environ. Eng. 1996, 122, 902-908. [CrossRef]

91. OCHA-IRAQ Iraq-Datasets 2018. Available online: www.unocha.org/iraq/about-ocha-iraq (accessed on 27 February 2021).

92. Al-Rubaiay, A.T.; Al-Dulaimi, T.Y. Series of Land Use Land Cover Maps of Iraq Scale 1:250 000, Sulaimaniya Quadrangle Sheet NI-38-3 (LULCM 10); GEOSURV: Baghdad, Iraq, 2012.

93. Sai Krishna, V.V.; Pandey, K.; Karnatak, H. Geospatial multicriteria approach for solid waste disposal site selection in Dehradun city, India. Curr. Sci. 2017, 112, 549-559. [CrossRef]

94. Rouse, J.W.; Haas, R.H.; Schelle, J.A.; Deering, D.W.; NASA/GSFC. Monitoring the Vernal Advancement or Retrogradation of Natural Vegetation; NASA: Greenbelt, MD, USA, 1974.

95. Mulliner, E.; Malys, N.; Maliene, V. Comparative analysis of MCDM methods for the assessment of sustainable housing affordability. Omega 2016, 59, 146-156. [CrossRef]

96. Guitouni, A.; Martel, J.-M. Tentative guidelines to help choosing an appropriate MCDA method. Eur. J. Oper. Res. 1998, 109, 501-521. [CrossRef]

97. Roy, B.; Słowiński, R. Questions guiding the choice of a multicriteria decision aiding method. EURO J. Decis. Process. 2013, 1, 69-97. [CrossRef]

98. Triantaphyllou, E. Multi-Criteria Decision Making Methods: A Comparative Study; Applied Optimization; Springer: Berlin/Heidelberg, Germany, 2000; ISBN 9780792366072.

99. Hwang, C.L.; Yoon, K. Multiple Attribute Decision Making: Methods and Applications A State-of-the-Art Survey; Lecture Notes in Economics and Mathematical Systems; Springer: Berlin/Heidelberg, Germany, 2012; ISBN 9783642483189.

100. Milillo, P.; Perissin, D.; Salzer, J.T.; Lundgren, P.; Lacava, G.; Milillo, G.; Serio, C. Monitoring dam structural health from space: Insights from novel InSAR techniques and multi-parametric modeling applied to the Pertusillo dam Basilicata, Italy. Int. J. Appl. Earth Obs. Geoinf. 2016, 52, 221-229. [CrossRef]

101. Afzali, A.; Sabri, S.; Rashid, M.; Mohammad Vali Samani, J.; Ludin, A.N.M. Inter-Municipal Landfill Site Selection Using Analytic Network Process. Water Resour. Manag. 2014, 28, 2179-2194. [CrossRef]

102. Baiocchi, V.; Lelo, K.; Polettini, A.; Pomi, R. Land suitability for waste disposal in metropolitan areas. Waste Manag. Res. 2014, 32, 707-716. [CrossRef]

103. Delgado, O.B.; Mendoza, M.; Granados, E.L.; Geneletti, D. Analysis of land suitability for the siting of inter-municipal landfills in the Cuitzeo Lake Basin, Mexico. Waste Manag. 2008, 28, 1137-1146. [CrossRef]

104. Lin, H.-Y.; Kao, J.-J. Grid-based heuristic method for multifactor landfill siting. J. Comput. Civ. Eng. 2005, 19, 369-376. [CrossRef]

105. Islam, A.; Ali, S.M.; Afzaal, M.; Iqbal, S.; Zaidi, S.N.F. Landfill sites selection through analytical hierarchy process for twin cities of Islamabad and Rawalpindi, Pakistan. Environ. Earth Sci. 2018, 77, 72. [CrossRef]

106. Sizirici, B.; Tansel, B.; Kumar, V. Knowledge based ranking algorithm for comparative assessment of post-closure care needs of closed landfills. Waste Manag. 2011, 31, 1232-1238. [CrossRef] [PubMed]

107. Othman, A.A.; Al-Maamar, A.F.; Al-Manmi, D.A.M.; Veraldo, L.; Hasan, S.E.; Obaid, A.K.; Al-Quraishi, A.M.F. GIS-based modeling for selection of dam sites in the Kurdistan Region, Iraq. ISPRS Int. J. Geo-Inf. 2020, 9, 244. [CrossRef]

108. Bellehumeur, C.; Vasseur, L.; Ansseau, C.; Marcos, B. Implementation of a multicriteria sewage sludge management model in the southern Quebec municipality of Lac-Megantic, Canada. J. Environ. Manag. 1997, 50, 51-66. [CrossRef]

109. Daghouri, A.; Mansouri, K.; Qbadou, M. Multi criteria decision making methods for information system selection: A comparative study. In Proceedings of the 2018 International Conference on Electronics, Control, Optimization and Computer Science, ICECOCS 2018, Kenitra, Morocco, 5-6 December 2018. 
110. Chakraborty, S.; Zavadskas, E.K.; Antucheviciene, J. Applications of WASPAS method as a multi-criteria decision-making tool. Econ. Comput. Econ. Cybern. Stud. Res. 2015, 49, 5-22.

111. Yal, G.P.; Akgün, H. Landfill site selection and landfill liner design for Ankara, Turkey. Environ. Earth Sci. 2013, 70, $2729-2752$. [CrossRef]

112. Mokhtarian, M.N.; Sadi-Nezhad, S.; Makui, A. A new flexible and reliable IVF-TOPSIS method based on uncertainty risk reduction in decision making process. Appl. Soft Comput. J. 2014, 23, 509-520. [CrossRef]

113. Aghajani Mir, M.; Taherei Ghazvinei, P.; Sulaiman, N.M.N.; Basri, N.E.A.; Saheri, S.; Mahmood, N.Z.; Jahan, A.; Begum, R.A.; Aghamohammadi, N. Application of TOPSIS and VIKOR improved versions in a multi criteria decision analysis to develop an optimized municipal solid waste management model. J. Environ. Manag. 2016, 166, 109-115. [CrossRef]

114. Akbass, H.; Bilgen, B. An integrated fuzzy QFD and TOPSIS methodology for choosing the ideal gas fuel at WWTPs. Energy 2017, 125, 484-497. [CrossRef]

115. Sabaghi, M.; Mascle, C.; Baptiste, P. Evaluation of products at design phase for an efficient disassembly at end-of-life. J. Clean. Prod. 2016, 116, 177-186. [CrossRef]

116. Maimoun, M.; Madani, K.; Reinhart, D. Multi-level multi-criteria analysis of alternative fuels for waste collection vehicles in the United States. Sci. Total Environ. 2016, 550, 349-361. [CrossRef]

117. Avikal, S.; Jain, R.; Mishra, P.K. A Kano model, AHP and M-TOPSIS method-based technique for disassembly line balancing under fuzzy environment. Appl. Soft Comput. J. 2014, 25, 519-529. [CrossRef]

118. Asefi, H.; Lim, S. A novel multi-dimensional modeling approach to integrated municipal solid waste management. J. Clean. Prod. 2017, 166, 1131-1143. [CrossRef]

119. Li, J.; Yang, Y.; Huan, H.; Li, M.; Xi, B.; Lv, N.; Wu, Y.; Xie, Y.; Li, X.; Yang, J. Method for screening prevention and control measures and technologies based on groundwater pollution intensity assessment. Sci. Total Environ. 2016, 551-552, 143-154. [CrossRef] [PubMed]

120. Yıldırım, Ü.; Güler, C. Identification of suitable future municipal solid waste disposal sites for the Metropolitan Mersin (SE Turkey) using AHP and GIS techniques. Environ. Earth Sci. 2016, 75, 101. [CrossRef]

121. De Felicori, T.C.; Marques, E.A.G. Multicriteria decision analysis applied in the selection of suitable areas for disposal of solid waste in Zona da Mata, Minas Gerais, Brazil. J. Solid Waste Technol. Manag. 2017, 43, 47-64. [CrossRef]

122. Aksoy, E.; San, B.T. Geographical information systems (GIS) and Multi-Criteria Decision Analysis (MCDA) integration for sustainable landfill site selection considering dynamic data source. Bull. Eng. Geol. Environ. 2019, 78, 779-791. [CrossRef]

123. Saaty, T.L. The Analytic Hierarchy Process in Conflict Management. Int. J. Confl. Manag. 1990, 1, 47-68. [CrossRef]

124. Zhang, L.; Lavagnolo, M.C.; Bai, H.; Pivato, A.; Raga, R.; Yue, D. Environmental and economic assessment of leachate concentrate treatment technologies using analytic hierarchy process. Resour. Conserv. Recycl. 2019, 141, 474-480. [CrossRef]

125. Salar, S.G.; Othman, A.A.; Hasan, S.E. Identification of suitable sites for groundwater recharge in Awaspi watershed using GIS and remote sensing techniques. Environ. Earth Sci. 2018, 77, 701. [CrossRef]

126. Liang, H.; He, S.; Lei, X.; Bi, Y.; Liu, W.; Ouyang, C. Dynamic process simulation of construction solid waste (CSW) landfill landslide based on SPH considering dilatancy effects. Bull. Eng. Geol. Environ. 2019, 78, 763-777. [CrossRef]

127. Xiu, W.; Wang, S.; Qi, W.; Li, X.; Wang, C. Disaster Chain Analysis of Landfill Landslide: Scenario Simulation and Chain-Cutting Modeling. Sustainability 2021, 13, 5032. [CrossRef]

128. Lei, W.; Xiaoguang, C.; Ping, L.; Yuna, Q. Numerical analysis of dynamic characteristics of sludge-type slag landfill landslide. In Proceedings of the IOP Conference Series: Earth and Environmental Science, Virtual, China, 23-29 November 2021; Volume 676. [CrossRef]

129. Bera, A.; Mukhopadhyay, B.P.; Chowdhury, P.; Ghosh, A.; Biswas, S. Groundwater vulnerability assessment using GIS-based DRASTIC model in Nangasai River Basin, India with special emphasis on agricultural contamination. Ecotoxicol. Environ. Saf. 2021, 214, 112085. [CrossRef] [PubMed]

130. Le, T.N.; Tran, D.X.; Tran, T.V.; Gyeltshen, S.; Lam, T.V.; Luu, T.H.; Nguyen, D.Q.; Dao, T. V Estimating soil water susceptibility to salinization in the mekong river delta using a modified drastic model. Water 2021, 13, 1636. [CrossRef] 